\title{
34. MOST ABUNDANT DIATOM SPECIES IN WATER COLUMN ASSEMBLAGES FROM FIVE LEG 119 DRILL SITES IN PRYDZ BAY, ANTARCTICA: DISTRIBUTIONAL PATTERNS ${ }^{1}$
}

\author{
Sung-Ho Kang ${ }^{2}$ and Greta A. Fryxell ${ }^{2}$
}

\begin{abstract}
Austral summer surface and subsurface sampling of the water column was conducted at five drill sites (Sites 739743) and included 14 stations in Prydz Bay, East Antarctica, from $66^{\circ} \mathrm{S}$ to $68^{\circ} \mathrm{S}$ approximately along $75^{\circ} \mathrm{E}$, from 18 January through 3 February 1988 . The samples were taken from seven depths at each station, between the surface and $200 \mathrm{~m}$, to gain quantitative information on the composition, abundance, and distribution of the diatoms in water column assemblages in Prydz Bay.

Over 40 diatom species were found in Prydz Bay. The highest numbers of cells integrated through the top $200 \mathrm{~m}$ were found at Site 739 with $288 \times 10^{9}$ cells/ $\mathrm{m}^{2}$, and at Sites $740,741,742$, and 743 with $262 \times 10^{9}, 180 \times 10^{9}, 118 \times 10^{9}$, and $37.6 \times 10^{9}$ cells $/ \mathrm{m}^{2}$, in the order of average abundance, respectively, and also as a time series in the short growing season.

Two different distributional patterns were observed. Small pennate diatom species $(<20 \mu \mathrm{m})$, Nitzschia cylindrus, Nitzschia closterium, and Nitzschia curta, dominated at all drill sites and were distributed ubiquitously along the transect of sampling sites, while larger-celled $(>20 \mu \mathrm{m})$ diatom species, Chaetoceros dichaeta, Chaetoceros neglectus, and Corethron criophilum, were concentrated in the inner part of Prydz Bay. The smaller-celled diatom species influenced the total diatom cell density and showed similar patterns of distribution to the totals, whereas profiles of the largercelled diatom species showed similar patterns to the chlorophyll $a$ concentration. The larger-celled diatom species with their large cell volumes may affect the chlorophyll $a$ distribution pattern and represent a significant biomass source inshore.

Cluster analysis revealed different relationships depending on which variables were used for the analysis. When only larger-celled diatom species were included in the analysis, stations were separated clearly into those from the inner part of Prydz Bay (Sites 740 and 741) and those from the outer part of Prydz Bay (Sites 739, 742, and 743). But when only smaller-celled diatom species were used for analysis, the stations from inner and outer Prydz Bay intermingled and were not separated clearly.

Diatom cell maxima were located slightly above the seasonal thermocline while chlorophyll $a$ maxima were located in the thermocline, slightly below the diatom cell maxima. Vertical diatom distributions mirrored the physical structure in the bay. Principal component analysis (PCA) using diatom cell density (cells/L) and chlorophyll $a$ concentration $(\mu \mathrm{g} / \mathrm{L})$ from discrete water samples (seven depths) as variables revealed that the samples from the Prydz Bay drill sites not only separated based on depth (above thermocline vs. below thermocline), but they also separated based on station.
\end{abstract}

\section{INTRODUCTION}

The main quantitative diatom studies have covered extensive areas of the Southern Ocean (Hart, 1942; Boden, 1949; Hasle, 1956, 1969; Marumo, 1957; Kozlova, 1966; Zernova, 1970; Steyaert, 1973a, b, 1974; Jacques et al., 1979), while very few are related to inshore waters. Only Hasle (1969), Steyaert (1973a, b, 1974) and Jacques et al. (1979) used Utermohl's (1958) sedimentation method. Reid (1983), Hewes et al. (1984), and Kang and Fryxell (1989) provide evidence that the traditionally used sedimentation technique of Utermohl may underestimate densities of nannoplankton when compared to the filter technique. The nannoplanktonic diatoms (generally considered to be $<20$ $\mu \mathrm{m}$ in size) such as Nitzschia cylindrus (Grunow) Hasle dominate and account for a high proportion of the biomass and primary production in the Southern Ocean. Weber and El-Sayed (1987) found the contribution of nannoplankton to integrated water column chlorophyll $a$ was $64 \%-76 \%$ of the total chlorophyll $a$ concentration in the region of the Antarctic Peninsula. In order to understand the trophodynamics of the nannoplank-

\footnotetext{
${ }^{1}$ Barron, J., Larsen, B., et al., 1991. Proc. ODP, Sci. Results, 119: College Station, TX (Ocean Drilling Program).

2 Department of Oceanography, Texas A\&M University, College Station, TX 77843 , U.S.A.
}

ton in the Southern Ocean, the generally used techniques for microscopical analysis and subsequent biomass estimation of these populations must be improved.

Little has been reported on the spatial and temporal variations of diatom species composition and abundance over an austral summer period in inshore waters. The specific factors controlling the distribution of Antarctic diatoms on broad spatial and temporal scales have not been resolved (Allanson et al., 1981), but recent studies have shown the importance of localized physical processes in promoting phytoplankton biomass accumulation in the Southern Ocean, as well as the seasonal light changes. Some of the important physicochemical factors that regulate phytoplankton abundance include nitrate flux, pycnocline location, and vertical stability (Seliger et al., 1981).

In contrast to the situation in winter when salt rejection from forming ice leads to intense haline convection, mixing of the summer surface water is usually due to wind forcing. Winddriven upwelling events have also been considered to trigger diatom blooms, resulting in the enrichment of the waters. It is assumed that the development of diatom blooms during the Ocean Drilling Program (ODP) Leg 119's occupation of Prydz Bay, from 18 January through 3 February 1988, requires in part that sea ice diatoms can act as an inoculum following receding ice edges. Garrison et al. (1987) found that the high degree of similarity between ice and water column assemblages. The spatial and temporal patterns in the distribution and abundances of species provide some evidence of seeding from sea ice of some 
diatom species in Southern Ocean, although bloom species can be advected in from the open water (Fryxell and Kendrick, 1988).

ODP Leg 119 took part in a study to map the climatic and oceanographic evolution of the Southern Ocean. The Prydz Bay region is an ideal study area for evaluation of the glacial record and the first development of a full-scale ice sheet in East Antarctica, because Prydz Bay lies at the mouth of the Lambert Glacier-Amery Ice Shelf system that drains about a fifth of East Antarctica (Leg 119 Shipboard Scientific Party, 1988). In order to study the evolution of glaciation and to document preglacial environments in East Antarctica, five drill sites were occupied in Prydz Bay, East Antarctica.

While JOIDES Resolution carried out drilling in Prydz Bay, most of the diatom-dominated phytoplankton collections were made from the ice support vessel, Maersk Master, which was assigned the task of protecting the drilling operation by moving drifting icebergs away from JOIDES Resolution. When ice conditions allowed, permission was given for the escort vessel to move around the drill ship and to carry out scientific operations. These operations included deploying and recovering sediment trap arrays, temperature and salinity profiling, light penetration measurements, phytoplankton net tows, and water sampling.

The objectives of this research are to (1) gain quantitative information on the composition, abundance, and distribution of the diatoms in water column assemblages associated with the Prydz Bay drill sites; (2) investigate the changes of horizontal and vertical diatom distribution with changing oceanographic conditions between drill sites; and (3) examine the differences of distribution pattern between diatom cells and chlorophyll $a$ concentration, based on species composition.

\section{Physical and Hydrographic Setting in the Region of Prydz Bay}

The continental shelf region known as Prydz Bay, East Antarctica, between the West Ice Shelf (around $80^{\circ} \mathrm{E}$ ) and Cape Darnley $\left(70^{\circ} \mathrm{E}\right)$ and the region off the Mawson coast (Fig. 1) are often ice-covered, similar to the two major Antarctic coastal seas, the Weddell and Ross seas (Smith et al., 1984). However, both the areal extent of the continental shelf and the dimensions of the major ice shelves within Prydz Bay are far smaller than the corresponding features of the Weddell and Ross seas.

Previous observations over the continental shelf in Prydz Bay (Zverev, 1959, 1963; Izvekov, 1959; Smith et al., 1984) showed relatively warm water in the surface layer and cold water at depth. The water depth in Prydz Bay is generally $<800 \mathrm{~m}$. The temporal and spatial variability of the ice conditions are important factors in the hydrological balance, particularly with respect to the surface structure (Denisov and Myznhikova, 1978). Through the summer season, the Antarctic Surface Water mass in Prydz Bay may be conveniently subdivided into summer surface water and continental shelf water (Smith et al., 1984).

Summer surface water is recognizable as a relatively warm $\left(0^{\circ}-2^{\circ} \mathrm{C}\right)$ and fresh $(33.5 \%-34 \%)$, highly variable layer above the seasonal thermocline and halocline, characteristics indicative of the summer heating and melting that led to its formation. During the occupation of Leg 119 in Prydz Bay, the structure of the surface layer depended upon local sea-surface conditions. Although all stations showed a well-developed summer surface water layer, there was structure in the surface layer. The mechanics of the evolution of such surface thermohaline structures is not clear, but it is likely that horizontal advection by wind-forcing, the proximity of the local ice shelves, and summer heating of surface water play important roles. The base of the summer surface layer has been assumed to correspond with the top of the seasonal thermocline in the $20-50-\mathrm{m}$ depth range
(Smith et al., 1984). The thickness of the surface layer generally increases to the north outside Prydz Bay, consistent with its relationship to the density of the ice coverage.

Below the highly variable summer surface water lies relatively low-temperature $\left(<0^{\circ} \mathrm{C}\right)$ and high-salinity $(>34 \% 0)$ continental shelf water. In comparison with the Weddell and Ross seas, where high-salinity shelf water is particularly prevalent, the volume in Prydz Bay is relatively small. The geography and bathymetry of Prydz Bay, and in particular the absence of broad shelf areas, are likely to be important factors in the production of high-salinity shelf water within Prydz Bay (Smith et al., 1984).

The principal surface water flow associated with the Antarctic Circumpolar Current is driven eastward by the prevailing westerlies (Jacobs and Georgi, 1977; Gordon et al., 1978). To the south the prevailing winds are to the west, giving rise to a divergence zone (around $65^{\circ} \mathrm{S}$ ) in the surface layer commonly referred to as the Antarctic Divergence (Tolstikov, 1966). South of the divergence zone the East Wind Drift dominates. An atmospheric low-pressure belt encircles the continent, this being the residue of the many depressions that track from west to east around this latitude (Deacon, 1982).

The water masses and circulation within Prydz Bay resemble those of similar sites within the Weddell and Ross seas, but there are significant differences in the large-scale circulations and in the geostrophic and topographic constraints imposed on the flows (Smith et al., 1984). Within Prydz Bay the present data show a closed cyclonic gyre (Grigor'yev, 1967; Savatiugin and Komova, 1971; Smith et al., 1984). Smith et al. (1984) observed icebergs off Princess Elizabeth Land moving southwest, while those calved from the Amery Ice Shelf normally follow the western periphery of Prydz Bay toward Cape Darnley. Observation of pack ice movement, iceberg tracks, and buoy trajectories near the Antarctic coast provide additional evidence of a westward coastal current (Swithinbank et al., 1977; Tchernia and Jeannin, 1980).

\section{METHODS}

\section{Data Collection}

Most of the diatom-dominated collections were made from Maersk Master and were conducted at the five drill sites (Sites 739-743) and included 14 stations approximately along $75^{\circ} \mathrm{E}$ in Prydz Bay, from $66^{\circ} \mathrm{S}$ to $68^{\circ} \mathrm{S}$, from 18 January through 3 February 1988 (see Fig. 1 and Table 1 for the location of the Prydz Bay drill sites and station locations). Site 739 is located $30 \mathrm{~km}$ landward from the continental shelf edge, and represents the most seaward of the sites drilled on the Prydz Bay continental shelf. The water depth was $412.3 \mathrm{~m}$. Site 742 is located $60 \mathrm{~km}$ landward from the shelf break, $170 \mathrm{~km}$ from Antarctica, in the outer part of the bay along the Leg 119 Prydz Bay drilling transect. The water depth was $410 \mathrm{~m}$. Sites 740 and 741 are situated in the inner part of Prydz Bay on the East Antarctic Continental shelf. The water depths were $816 \mathrm{~m}$ and $561 \mathrm{~m}$, respectively. Site 743 is situated on the upper continental slope of Prydz Bay in $987 \mathrm{~m}$ water depth (See fig. 2 in Leg 119 Shipboard Scientific Party, 1988).

Secchi disk readings were taken at each station to determine the euphotic zone (EZ), assumed to extend to a depth corresponding to $1 \%$ of light intensity at the surface. The following formula (based on Evans et al., 1987) was used to determine the depth of the euphotic zone.

$$
\mathrm{EZ}(\mathrm{m})=\ln \frac{1}{100} \times \frac{\text { Secchi depth }(\mathrm{m})}{-1.7}
$$

Three types of diatom samples were collected at the Prydz Bay drill stations to achieve the goals listed in the preceding: 


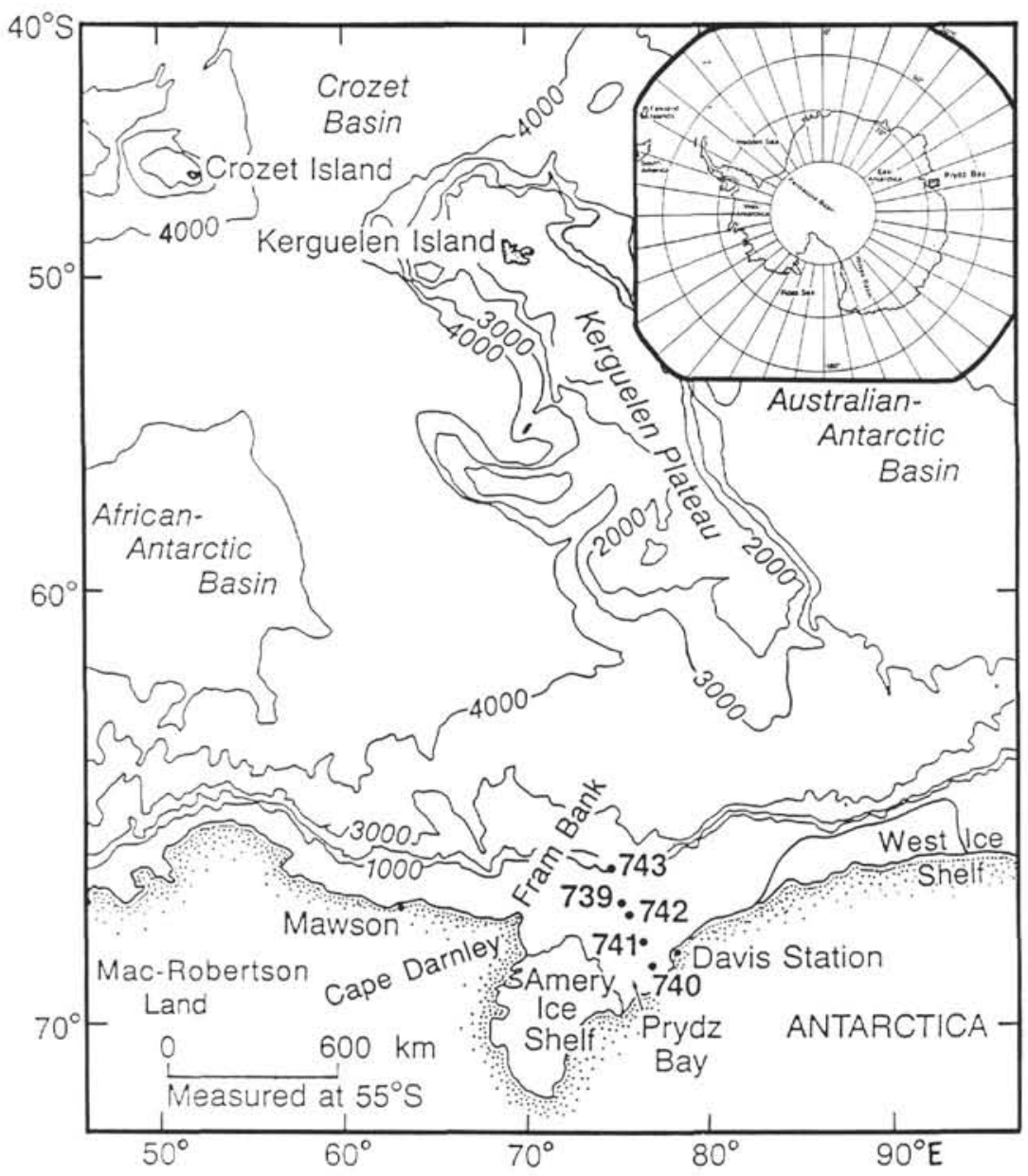

Figure 1. Location of Ocean Drilling Program drill sites in Prydz Bay, East Antarctica, during Leg 119. Bathymetric contours shown in meters. Continental shelf break is situated between Site 739 and Site 743 at approximately $415 \mathrm{~m}$ water depth.

whole water samples, vertical and oblique standard phytoplankton net tows, and opening-and-closing vertical net hauls.

Discrete water samples were collected from seven depths in the water column at 14 stations. Seawater sampling depths were chosen from the SEACAT conductivity-temperature-depth (CTD) recorder data. The CTD profiles were taken before the water casts so that water collection bottles could be placed at desired depths in relation to the mixed layer. The water samples were collected between 0 and $200 \mathrm{~m}$ with a bucket for surface samples and a series of Niskin bottles for subsurface samples. See Figure 2 for temperature $\left({ }^{\circ} \mathrm{C}\right)$ and salinity $(\% 0)$ profiles at the CTD stations.

Aliquots $(125 \mathrm{~mL})$ from the bucket and bottles were preserved with a final concentration of $1 \%-2 \%$ glutaraldehyde and transported to the laboratory at Texas A\&M University (TAMU) to compare results using filtered (HPMA, prepared on board ship) and settled (Utermohl) techniques in a shore-based study (Kang and Fryxell, 1989). Standard phytoplankton net tows (35$\mu \mathrm{m}$ mesh) and opening-and-closing net hauls were taken at each CTD station and preserved with 1\%-2\% glutaraldehyde. These concentrated samples enabled us to examine the rare component of the diatoms. The preserved water samples and concentrated net samples were placed in 250 and $125 \mathrm{~mL}$ bottles with a glass coverslip in each bottle to avoid some silica dissolution problems during shipment to TAMU.

The following major works were used for the identification of the Antarctic diatoms: Karsten (1905), Hendey (1937), Hu- stedt (1958), Manguin (1960), and Priddle and Fryxell (1985). For the identification of the genus Thalassiosira Cleve the following works were used: Fryxell (1977), Fryxell et al. (1979, 1981), Fryxell and Hasle (1983), and Johansen and Fryxell (1985). Publications by Hasle (1964, 1965a, b, 1968, 1972a, b, 1974) were used in relation to the important Antarctic genus Nitzschia Hassall.

A newly described quantitative method utilizing filtered samples (Crumpton, 1987) was used (Kang and Fryxell, 1989). The seawater samples were filtered and mounted directly in the water-soluble resin (HPMA, 2-hydroxypropyl methacrylate) on board Maersk Master. The HPMA slides were used for absolute cell counts to gain quantitative information on the composition, abundance, and distribution of diatom species from different water depths at each station.

\section{Data Analysis}

Diatom cells were enumerated for this study using the HPMA technique. A Zeiss ICM-405 microscope was used with phase contrast or bright-field illumination at $400 \times$. At least 300 diatom cells were counted to attain a $95 \%$ probability of finding an organism present at the $1 \%$ relative abundance level in the population, assuming the cells are randomly distributed on the HPMA slide and in the settling chamber (Shaw, 1964).

The number of diatom cells per liter of seawater was obtained by counting numbers of cells per unit area and correcting for total area ( $269 \mathrm{~mm}^{2}$ for the HPMA technique) and volume 
Table 1. Locations of sample sites and summary of hydrocasts and net hauls made from Maersk Master during ODP Leg 119.

\begin{tabular}{|c|c|c|c|c|c|c|c|}
\hline $\begin{array}{l}\text { Station } \\
\text { date } \\
(1988)\end{array}$ & Drill site & $\begin{array}{c}\text { Position } \\
\text { (Lat./Long.) }\end{array}$ & $\begin{array}{c}\text { Water } \\
\text { sample }\end{array}$ & $\begin{array}{l}\text { Standard } \\
\text { phyto- } \\
\text { plankton } \\
\text { net tow }\end{array}$ & $\begin{array}{l}\text { Opening- } \\
\text { and- } \\
\text { closing } \\
\text { net haul }\end{array}$ & $\begin{array}{l}\text { Depth of } \\
\text { euphotic } \\
\text { zone } \\
\text { (m) }\end{array}$ & $\begin{array}{l}\text { Water } \\
\text { depth } \\
\text { (m) }\end{array}$ \\
\hline $\begin{array}{l}119-1 \\
18 \text { Jan. }\end{array}$ & $\begin{array}{c}\text { Site } 739 \\
\text { Outer Prydz Bay }\end{array}$ & $\begin{array}{l}67^{\circ} 15^{\prime} \mathrm{S} \\
75^{\circ} 00^{\prime} \mathrm{E}\end{array}$ & $\mathrm{x}$ & $\mathrm{x}$ & $\mathrm{x}$ & 13.5 & \\
\hline $\begin{array}{l}119-2 \\
19 \text { Jan. }\end{array}$ & $\begin{array}{c}\text { Site } 739 \\
\text { Outer Prydz Bay }\end{array}$ & $\begin{array}{l}67^{\circ} 17^{\prime} \mathrm{S} \\
75^{\circ} 04^{\prime} \mathrm{E}\end{array}$ & $\mathrm{x}$ & $\mathrm{x}$ & $\mathrm{x}$ & 16.2 & 412 \\
\hline $\begin{array}{l}119-3 \\
21 \text { Jan. }\end{array}$ & $\begin{array}{c}\text { Site } 739 \\
\text { Outer Prydz Bay }\end{array}$ & $\begin{array}{l}67^{\circ} 17^{\prime} \mathrm{S} \\
75^{\circ} 01^{\prime} \mathrm{E}\end{array}$ & $\mathrm{x}$ & $\mathrm{x}$ & $\mathrm{x}$ & 21.7 & \\
\hline $\begin{array}{l}119-4 \\
22 \text { Jan. }\end{array}$ & $\begin{array}{c}\text { Site } 739 \\
\text { Outer Prydz Bay }\end{array}$ & $\begin{array}{l}67^{\circ} 17^{\prime} \mathrm{S} \\
75^{\circ} 05^{\prime} \mathrm{E}\end{array}$ & $\mathrm{x}$ & $\mathrm{x}$ & $x$ & 20.3 & \\
\hline $\begin{array}{l}119-5 \\
24 \text { Jan. }\end{array}$ & $\begin{array}{c}\text { Site } 740 \\
\text { Inner Prydz Bay }\end{array}$ & $\begin{array}{l}68^{\circ} 42^{\prime} \mathrm{S} \\
76^{\circ} 40^{\prime} \mathrm{E}\end{array}$ & $\mathrm{X}$ & $x$ & $x$ & 10.8 & \\
\hline $\begin{array}{l}119-6 \\
25 \text { Jan. }\end{array}$ & $\begin{array}{c}\text { Site } 740 \\
\text { Inner Prydz Bay }\end{array}$ & $\begin{array}{l}68^{\circ} 39^{\prime} \mathrm{S} \\
76^{\circ} 35^{\prime} \mathrm{E}\end{array}$ & $\mathrm{x}$ & $\mathrm{x}$ & $\mathrm{x}$ & 10.8 & 816 \\
\hline $\begin{array}{l}119-7 \\
26 \text { Jan. }\end{array}$ & $\begin{array}{c}\text { Site } 740 \\
\text { Inner Prydz Bay }\end{array}$ & $\begin{array}{l}68^{\circ} 41^{\prime} \mathrm{S} \\
76^{\circ} 41^{\prime} \mathrm{E}\end{array}$ & $x$ & $x$ & $\mathrm{x}$ & 13.5 & \\
\hline $\begin{array}{c}119-8 \\
27 \text { Jan. }\end{array}$ & $\begin{array}{c}\text { Site } 740 \\
\text { Inner Prydz Bay }\end{array}$ & $\begin{array}{l}68^{\circ} 42^{\prime} \mathrm{S} \\
76^{\circ} 39^{\prime} \mathrm{E}\end{array}$ & $\mathrm{x}$ & $\mathrm{x}$ & $\mathrm{x}$ & 10.8 & \\
\hline $\begin{array}{l}119-9 \\
28 \text { Jan. }\end{array}$ & $\begin{array}{c}\text { Site } 741 \\
\text { Inner Prydz Bay }\end{array}$ & $\begin{array}{l}68^{\circ} 24^{\prime} \mathrm{S} \\
76^{\circ} 21^{\prime} \mathrm{E}\end{array}$ & $\mathrm{x}$ & $\mathrm{x}$ & $\mathrm{x}$ & 10.8 & 561 \\
\hline $\begin{array}{l}119-10 \\
29 \text { Jan. }\end{array}$ & $\begin{array}{c}\text { Site } 741 \\
\text { Inner Prydz Bay }\end{array}$ & $\begin{array}{l}68^{\circ} 24^{\prime} \mathrm{S} \\
76^{\circ} 20^{\prime} \mathrm{E}\end{array}$ & $\mathrm{x}$ & $\mathrm{x}$ & $\mathrm{x}$ & 9.5 & \\
\hline $\begin{array}{l}\text { 119-11 } \\
\text { 31 Jan. }\end{array}$ & $\begin{array}{c}\text { Site } 742 \\
\text { Outer Prydz Bay }\end{array}$ & $\begin{array}{l}67^{\circ} 32^{\prime} \mathrm{S} \\
75^{\circ} 30^{\prime} \mathrm{E}\end{array}$ & $\mathrm{x}$ & $\mathrm{x}$ & $\mathrm{x}$ & 20.3 & 410 \\
\hline $\begin{array}{l}119-12 \\
1 \mathrm{Feb} .\end{array}$ & $\begin{array}{c}\text { Site } 742 \\
\text { Outer Prydz Bay }\end{array}$ & $\begin{array}{l}67^{\circ} 34^{\prime} \mathrm{S} \\
75^{\circ} 30^{\prime} \mathrm{E}\end{array}$ & $\mathrm{x}$ & $\mathrm{x}$ & $\mathrm{x}$ & 20.3 & \\
\hline $\begin{array}{l}119-13 \\
2 \mathrm{Feb} .\end{array}$ & $\begin{array}{c}\text { Site } 743 \\
\text { Outer Prydz Bay }\end{array}$ & $\begin{array}{l}66^{\circ} 52^{\prime} \mathrm{S} \\
74^{\circ} 38^{\prime} \mathrm{E}\end{array}$ & $\mathrm{x}$ & $\mathrm{x}$ & $\mathrm{x}$ & 30.4 & 987 \\
\hline $\begin{array}{l}119-14 \\
3 \mathrm{Feb} .\end{array}$ & $\begin{array}{c}\text { Site } 743 \\
\text { Outer Prydz Bay }\end{array}$ & $\begin{array}{l}66^{\circ} 57^{\prime} \mathrm{S} \\
74^{\circ} 42^{\prime} \mathrm{E}\end{array}$ & $\mathrm{x}$ & $\mathrm{x}$ & $\mathrm{x}$ & 27.1 & \\
\hline
\end{tabular}

used. The diatom cell abundance per liter (A) is calculated as follows:

where

$$
\mathrm{A}(\text { cells } / \mathrm{L})=\frac{1000 \mathrm{~mL} / \mathrm{L}}{\mathrm{FV}(\mathrm{mL})} \times \frac{\mathrm{TA}\left(\mathrm{mm}^{2}\right)}{\mathrm{CA}\left(\mathrm{mm}^{2}\right)} \mathrm{CN},
$$

$\mathrm{A}=$ number of diatom cells $/ \mathrm{L}$,

$\mathrm{FV}=$ volume of the filtered water sample $(\mathrm{mL})$,

TA $=$ area of the filtering chamber $\left(\mathrm{mm}^{2}\right)$,

$\mathrm{CA}=$ area of the counted area $\left(\mathrm{mm}^{2}\right)$,

$\mathrm{CN}=$ number of diatom cells counted .

The cells per liter were calculated from the raw microscope counts using a FORTRAN program. These values were subsequently stored as FORTRAN datasets on the TAMU Oceanography Department VAX computer for contour plots and as data sets on a Macintosh personal computer for other graphs.

The quantitative estimates of the abundant components of the diatoms are compared to assess variation with depth, variation between stations and between drill sites, variation over an austral summer period, and variation of distribution pattern between diatom cells and chlorophyll concentration, based on species composition.

Statistics were aided by the Statistical Analysis System (SAS) for the VAX computer and SYSTAT and STATWORKS for the Macintosh personal computer. Principal component analysis (PCA) was performed with the SAS and is based on the correlation matrix. Cluster analysis was performed on stations to help clarify relationships between stations and drill sites. We used an average linkage technique for agglomerative hierarchical clustering of stations using integrated absolute abundances $\left(\mathrm{cell} / \mathrm{m}^{2}\right)$ of dominant diatom species to $200 \mathrm{~m}$ depth as variables.

\section{RESULTS}

\section{Integrated Diatom Abundances}

The integrated absolute and relative diatom abundances for Prydz Bay drill sites are tabulated (Table 2) and plotted (Figs. 3 and 4). Estimated numbers of total full diatoms (assumed to be alive when collected) integrated throughout a water column $1 \mathrm{~m}^{2}$, weighted by depth, ranged almost an order of magnitude from $37.6 \times 10^{9}$ cells $/ \mathrm{m}^{2}$ at Site 743 , to $288 \times 10^{9}$ cells $/ \mathrm{m}^{2}$ at Site 739 , while total empty diatoms (assumed to be dead when collected) ranged only from $71.6 \times 10^{9}$ cells $/ \mathrm{m}^{2}$ at Site 741 , to $122 \times 10^{9}$ cells $/ \mathrm{m}^{2}$ at Site 740 .

Examination of each dominant diatom species separately at each drill site showed that the main components of the total full diatoms were small pennate diatoms $(<20 \mu \mathrm{m})$ Nitzschia cylindrus, Nitzschia closterium, and Nitzschia curta and larger-celled diatoms $(>20 \mu \mathrm{m})$ Chaetoceros dichaeta, Chaetoceros neglectus, and Corethron criophilum. The most abundant taxa listed by drill site were determined by taking the mean integrated abundances of all species observed at the Prydz Bay drill sites and ranking them.

Nitzschia closterium attained the highest integrated numbers at Site $739\left(188 \times 10^{9}\right.$ cells $\left./ \mathrm{m}^{2}\right)$ with the lowest numbers at Site $743\left(3.91 \times 10^{9}\right.$ cells $\left./ \mathrm{m}^{2}\right)$. The nannoplanktonic diatom, $N$. $c y$ - 


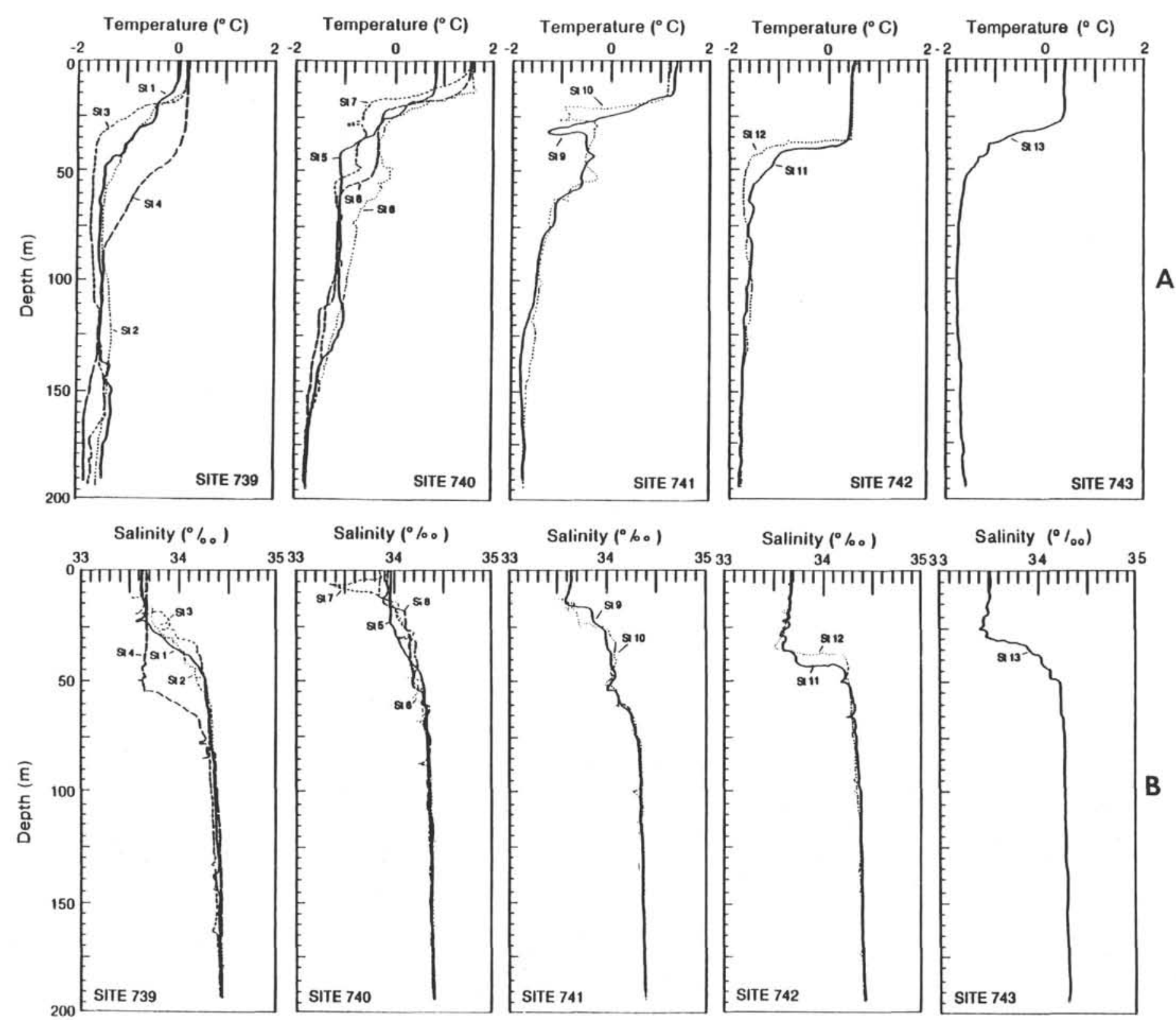

Figure 2. Temperature and salinity profiles at CTD stations grouped by Leg 119 drill sites. $\mathrm{St}=$ stations occupied during drilling operations at one drill site. 
Table 2. Average species abundance from water samples of Leg 119 drill sites.

\begin{tabular}{|c|c|c|c|c|c|}
\hline Species & Site 739 & Site 740 & Site 741 & Site 742 & Site 743 \\
\hline $\begin{array}{l}\text { Actinocyclus actinochilus } \\
\text { (Ehrenberg) Simonsen }\end{array}$ & $2.89 \times 10^{7}$ & $1.13 \times 10^{8}$ & $1.51 \times 10^{8}$ & $5.04 \times 10^{7}$ & + \\
\hline Asteromphalus parvulus Karsten & & $6.66 \times 10^{7}$ & $1.63 \times 10^{8}$ & & \\
\hline Chaetoceros atlanticus Cleve & & $2.63 \times 10^{8}$ & $2.58 \times 10^{8}$ & & \\
\hline $\begin{array}{l}\text { C. breve Schutt } \\
\text { C. bulbosus (Ehrenberg) Heiden }\end{array}$ & & & $313 \times 10^{7}$ & + & + \\
\hline $\begin{array}{l}\text { C. bulbosus (Ehrenberg) Heiden } \\
\text { C. convolutus Castracane }\end{array}$ & $3.23 \times 10^{7}$ & $1.17 \times 10^{8}$ & $\begin{array}{l}3.13 \times 10^{7} \\
3.07 \times 10^{8}\end{array}$ & & \\
\hline & $4.96 \times 10^{7}$ & स. & + & & \\
\hline C. dichaeta Ehrenberg & $1.01 \times 10^{9}$ & $3.24 \times 10^{9}$ & $1.23-10^{10}$ & $9.94 \times 10^{7}$ & $5.21 \times 10^{7}$ \\
\hline C. flexuosus Mangin & $7.27 \times 10^{8}$ & $1.90 \times 10^{8}$ & $4.06 \times 10^{8}$ & + & $7.91 \times 10^{7}$ \\
\hline C. neglectus Karsten & $3.08 \times 10^{9}$ & $1.44 \times 10^{10}$ & $2.25 \times 10^{10}$ & $4.41 \times 10^{8}$ & $1.53 \times 10^{8}$ \\
\hline C. neogracilis Van Lendingham & & & + & & \\
\hline C. pendulus Karsten & & & $3.39 \stackrel{+}{\times}$ & $2.80 \stackrel{+}{\times} \times 10^{8}$ & \\
\hline $\begin{array}{l}\text { C. sp. cf. wighamii (veg.) } \\
\text { Brightwell }\end{array}$ & $1.30 \times 10^{7}$ & $1.53 \times 10^{7}$ & $3.39 \times 10^{\circ}$ & $2.80 \times 10^{\circ}$ & 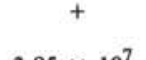 \\
\hline $\begin{array}{l}\text { C. sp. cf. wighamii (r.s.) } \\
\text { Brightwell }\end{array}$ & $1.03 \times 10^{9}$ & $3.15 \times 10^{9}$ & $1.30 \times 10^{9}$ & $1.16 \times 10^{9}$ & $3.95 \times 10^{7}$ \\
\hline Corethron criophilum Castracane & $8.88 \times 10^{8}$ & $9.53 \times 10^{9}$ & $1.84 \times 10^{10}$ & $3.29 \times 10^{8}$ & $2.34 \times 10^{8}$ \\
\hline $\begin{array}{l}\text { Dactyliosolen tenuijunctus } \\
\text { (Mangin) Hasle }\end{array}$ & & $7.91 \times 1$ & $3.20 \times$ & $1.79 \times 10^{8}$ & \\
\hline $\begin{array}{l}\text { Eucampia antartica } \\
\quad \text { (Castracane) Mangin }\end{array}$ & $2.52 \times 10^{8}$ & $9.23 \times 10^{8}$ & $1.88 \times 10^{8}$ & $4.51 \times 10^{7}$ & $2.08 \times 10^{7}$ \\
\hline $\begin{array}{l}\text { Leptocylindrus mediterraneus } \\
\text { (H. Peragallo) Hasle }\end{array}$ & $3.59 \times 10^{7}$ & + & + & + & $2.38 \times 10^{7}$ \\
\hline Navicula sp. & $4.16 \times 10^{7}$ & $1.17 \times 10^{8}$ & $1.10 \times 10^{8}$ & + & $2.23 \times 10^{8}$ \\
\hline $\begin{array}{l}\text { Nitzchia angulata } \\
\text { (O'Meara) Hasle }\end{array}$ & & $1.29 \times 10^{7}$ & $2.75 \times 10^{8}$ & $4.51 \times 10^{7}$ & $8.80 \times 10^{7}$ \\
\hline $\begin{array}{l}\text { N. closterium } \\
\text { (Ehrenberg) W. Smith }\end{array}$ & $1.88 \times 10^{11}$ & $8.59 \times 10^{10}$ & $3.87 \times 10^{10}$ & $6.23 \times 10^{10}$ & $3.91 \times 10^{9}$ \\
\hline N. curta (Van Heurck) Hasle & $6.81 \times 10^{9}$ & $3.86 \times 10^{9}$ & $6.20 \times 10^{9}$ & $7.10 \times 10^{9}$ & $1.29 \times 10^{9}$ \\
\hline N. cylindrus (Grunow) Hasle & $8.07 \times 10^{10}$ & $1.27 \times 10^{11}$ & $\begin{array}{l}7.09 \times 10^{10} \\
3.21 \times 10^{9}\end{array}$ & $4.37 \times 10^{10}$ & $2.90 \times 10^{10}$ \\
\hline $\begin{array}{l}\text { N. heimii Mangin } \\
\text { N. lecointei Van Heurck }\end{array}$ & $\begin{array}{l}4.97 \times 10^{8} \\
4.36 \times 10^{8}\end{array}$ & $\begin{array}{c}2.42 \times 10^{9} \\
+\end{array}$ & $\begin{array}{c}3.21 \times 10^{8} \\
+\end{array}$ & $\begin{array}{l}8.01 \times 10^{\prime} \\
2.99 \times 10^{8}\end{array}$ & $1.18 \stackrel{+}{\times} 10^{8}$ \\
\hline $\begin{array}{l}\text { N. obliquecostata } \\
\text { (Van Heurck) Hasle }\end{array}$ & $2.42 \times 10^{7}$ & $1.09 \times 10^{9}$ & $2.20 \times 10^{8}$ & $9.65 \times 10^{7}$ & \\
\hline $\begin{array}{l}N . \text { prolongatoides Hasle } \\
N \text {, pseudonana (Hasle) Hasle }\end{array}$ & $1.32 \times 10^{8}$ & $2.06 \times 10^{8}$ & $4.95 \times 10^{8}$ & $2.02 \times 10^{8}$ & $+0^{+}$ \\
\hline $\begin{array}{l}\text { udonana (Hasle) Hasle } \\
\text { cheri (Hustedt) Hasle }\end{array}$ & $\begin{array}{l}2.12 \times 10^{7} \\
1.94 \times 10^{8}\end{array}$ & $\stackrel{+}{+} 9$ & $1.89+19^{+}$ & $2.70 \times 10^{8}$ & $\begin{array}{c}5.55 \times 10^{8} \\
+\end{array}$ \\
\hline N. separanda (Hustedt) Hasle & $4.82 \times 10^{7}$ & $1.88 \times 10^{\circ}$ & $1.89 \times 10^{\circ}$ & $\begin{array}{c}2.70 \times 10^{\circ} \\
+\end{array}$ & $\begin{array}{l}+ \\
+\end{array}$ \\
\hline N. subcurvata Hasle & $1.17 \times 10^{9}$ & $1.71 \times 10^{7}$ & $7.45 \times 10^{8}$ & $1.52 \times 10^{8}$ & $1.20 \times 10^{9}$ \\
\hline $\begin{array}{l}\text { N. sublineata } \text { Hasle } \\
N \text {. turgiduloides Hasle }\end{array}$ & $2.30 \times 10^{8}$ & $1.56 \times 10^{9}$ & $6.65 \times 10^{7}$ & $3.01 \times 10^{8}$ & + \\
\hline $\begin{array}{l}\text { N. turgiduloides Hasle } \\
\text { Odontella weissflogii }\end{array}$ & $1.14 \times 10^{8}$ & $8.98 \times 10^{8}$ & $5.20 \times 10^{8}$ & $1.38 \times 10^{8}$ & + \\
\hline $\begin{array}{l}\text { Odontella weissflogii } \\
\text { (Janish) Grunow } \\
\text { Porosira pseudodenticulata }\end{array}$ & & $1.65 \times 10^{\circ}$ & & & \\
\hline $\begin{array}{l}\text { Porosira pseudodenticulata } \\
\text { (Hustedt) Jouse }\end{array}$ & $2.12 \times 10^{7}$ & $5.60 \times 10^{7}$ & 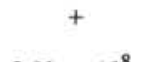 & & \\
\hline $\begin{array}{l}\text { Rhizosolenia alata Brightwell } \\
R \text {. hebetata f. semispina } \\
\text { (Hensen) Gran }\end{array}$ & $9.09 \times 10^{7}$ & $6.55 \times 10^{8}$ & $8.33 \times 10^{8}$ & $4.01 \times 10^{7}$ & \\
\hline $\begin{array}{l}\text { Stellarima microtrias Hasle et Sims } \\
\text { (Coscinodiscus furcatus } \text { Karsten) }\end{array}$ & $\begin{array}{l}1.29 \times 10^{7} \\
2.50 \times 10^{8}\end{array}$ & $6.47 \stackrel{+}{\times} 10^{8}$ & $2.51 \times 10^{8}$ & $2.04 \times 10^{8}$ & $4.39 \times$ \\
\hline $\begin{array}{l}\text { Thalassiosira sp. } \\
\text { Thalassiorthrix longissima }\end{array}$ & + & $\begin{array}{l}1.49 \times 10^{8} \\
2.40 \times 10^{7}\end{array}$ & $\begin{array}{c}3.26 \times 10^{8} \\
+\end{array}$ & + & $4.42 \times 10^{7}$ \\
\hline $\begin{array}{l}\text { Cleve et Grunow } \\
\text { Tropidoneis antarcticus } \\
\text { (Grunow) Cleve }\end{array}$ & $2.12 \times 10^{7}$ & $3.57 \times 10^{7}$ & & & \\
\hline $\begin{array}{l}\text { T. belgicae (Van Heurck) Heiden } \\
\text { T. glacialis Heiden }\end{array}$ & $\begin{array}{l}9.30 \times 10^{7} \\
6.19 \times 10^{8}\end{array}$ & $\begin{array}{l}1.80 \times 10^{8} \\
5.44 \times 10^{8}\end{array}$ & $3.08 \times 10^{8}$ & $1.06 \stackrel{+}{\times} 10^{9}$ & $3.16 \stackrel{+}{\times} 10^{8}$ \\
\hline $\begin{array}{l}T \text {. sp. cf. vanheurckii } \\
\text { (Van Heurck) Heiden et Kolbe }\end{array}$ & $1.05 \times 10^{7}$ & & & & \\
\hline
\end{tabular}

Note: $+=<10^{3}$ cells $/ \mathrm{m}^{3}$. Bold entries are the dominant diatom species at each site.

lindrus was in greatest abundance at Site $740\left(127 \times 10^{9}\right.$ cells/ $\left.\mathrm{m}^{2}\right)$ with the lowest abundance at Site $743\left(29 \times 10^{9}\right.$ cells $\left./ \mathrm{m}^{2}\right)$. N. curta attained the highest integrated numbers at Site 742 $\left(7.10 \times 10^{9}\right.$ cells $\left./ \mathrm{m}^{2}\right)$ with the lowest numbers at Site $743(1.29$ $\times 10^{9}$ cells $/ \mathrm{m}^{2}$ ). The small pennate diatom species $N$. closterium, $N$. cylindrus, and $N$. curta account for more than $90 \%$ of the total diatoms at the outer Prydz Bay drill sites (Sites 739, 742 , and 743 ) and less than $80 \%$ and $70 \%$ of total diatoms at the inner Prydz Bay drill sites (Sites 740 and 741), respectively.

The larger-celled diatoms, Chaetoceros dichaeta, C. neglectus, and Corethron criophilum were in greatest abundances at Site 741 , where they account for more than $25 \%$ of total dia- toms. Counts ranged from $22.5 \times 10^{9}$ cells $/ \mathrm{m}^{2}$ for Chaetoceros neglectus to $12.3 \times 10^{9}$ cells $/ \mathrm{m}^{2}$ of $C$. dichaeta. They were in lowest abundances at Site 743 , ranging from $0.23 \times 10^{9}$ cells/ $\mathrm{m}^{2}$ of Corethron criophilum, to $0.052 \times 10^{9}$ cells $/ \mathrm{m}^{2}$ of Chaetoceros dichaeta.

The mean ratio of empty diatoms to full diatoms was $0.32 / 1$ for Site $739,0.47 / 1$ for Site $740,0.40 / 1$ for Site $741,1.008 / 1$ for Site 742 , and $1.91 / 1$ for Site 743 (Fig. 3). Higher ratios of empty/full diatom frustules were found in the outer part of Prydz Bay, suggesting a generally declining population, or possibly grazing pressure, while lower ratios of empty/full diatom frustules were found in the inner part of Prydz Bay (Sites 740 


\section{INTEGRATED CELLS PER SQUARE METER \\ TOTAL FULL DIATOMS VS. EMPTY DIATOMS \\ PRYDZ BAY DRILL SITES, ODP LEG 119}

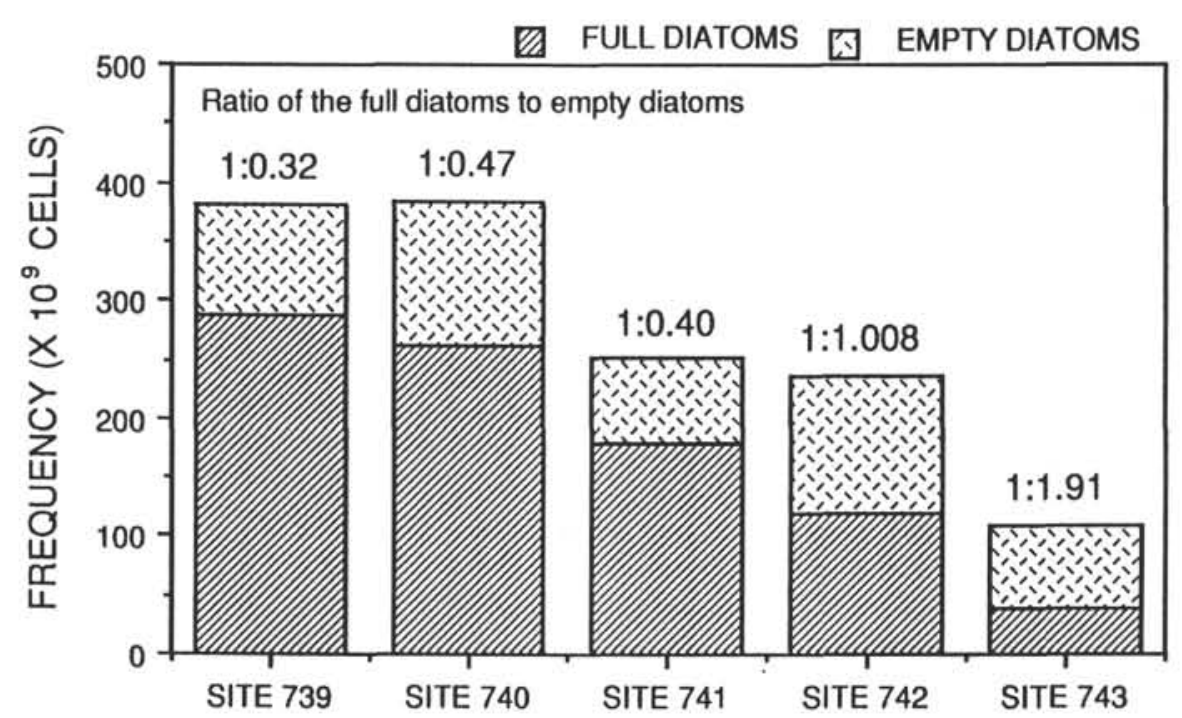

Figure 3. Integrated cells $/ \mathrm{m}^{2}$ of total full and empty diatoms and the ratio of empty diatoms to full diatoms at Leg 119 Prydz Bay drill sites.

and 741), suggesting a healthy, growing population, or low grazing pressure. The similarity in total numbers of empty cells at all sites also suggests suspended frustules after winter deaths.

Figure 4 shows the amplitudes of absolute and relative abundance changes of total full diatoms. The pattern of absolute abundances is different from the pattern of relative abundance. For example, the lowest integrated numbers of $N$. cylindrus were at Site 743 but the highest relative abundance of $N$. cylindrus was at Site 743. Thus, an event could go undetected if only relative abundances are examined.

\section{Distributional Patterns}

During an austral summer (18 January-3 February 1988) temporal and spatial diatom distributions in the water column from $66^{\circ} \mathrm{S}$ to $68^{\circ} \mathrm{S}$ approximately along $75^{\circ} \mathrm{E}$ were obtained from the ODP Leg 119 Prydz Bay drilling transect during an ice-free period. Nitzschia closterium appears to disintegrate when empty, but it was very abundant as the drilling started (Figs. 5A and 5B). Nitzschia closterium, considered as an ice-related diatom (Garrison and Buck, 1985), dominated most of the samples in addition to the nannoplanktonic diatom $N$. cylindrus, and showed a peak in abundance at Site $739\left(6.77 \times 10^{6}\right.$ cells/L) at $25 \mathrm{~m}$. Figure 4B shows that the maximum relative abundance of $N$. closterium occurred at Site $739(>65 \%)$ and lowest at Site 743 (approximately 10\%). The average abundance of $N$. closterium with depth showed also a peak abundance at Site 739 at 25 $\mathrm{m}$ depth. At Site 743 the average abundance was generally $<0.5$ $\times 10^{6}$ cells/L. Except at those two sites (739 and 743), however, the shapes of the curves were similar at the other drill sites (Sites 740,741 , and 742 ).

Chlorophyll $a$ concentration in the upper $200 \mathrm{~m}$ along the transect at the Prydz Bay drill sites was more in agreement with abundance of some of the larger diatoms rather than smaller diatoms such as $N$. closterium (Figs. 5 and 6 ). In general, there was a strong relationship between the physical structure (profiles of thermohalines) (Fig. 2) and biological structure (profiles of diatom abundances) (Figs. 7 and 8 ) in the bay during the aus- tral summer period. Maximum diatom abundances were situated above or embedded in the thermocline, and vertical symmetry of the physical and biological structures was apparent.

Total full diatoms at Site 739 showed a peak in abundance $\left(8.11 \times 10^{6}\right.$ cells $\left./ \mathrm{L}\right)$ in the $25-33-\mathrm{m}$ water depth range, made up principally of Nitzschia closterium, as was another peak in abundance of total full diatoms at Site 740 with $8.38 \times 10^{6}$ cells/ $\mathrm{L}$ at $10 \mathrm{~m}$. The total full diatom abundance decreased to the north from the inner Prydz Bay drill sites (Sites 740 and 741) to the outer drill sites (Sites 742 and 743), except at Site 739. Average abundance of the total full diatoms with depth in the upper $200 \mathrm{~m}$ for stations sampled at each drill site from Maersk Master showed high numbers of the total full diatoms in the upper $33 \mathrm{~m}$ (Figs. 7A and 7B). At Site 743 the full total diatoms showed a maximum in abundance $\left(0.95 \times 10^{6}\right.$ cells/L) in the upper $33 \mathrm{~m}$ water depth, where diatoms were distributed fairly uniformly with depth for the upper $33 \mathrm{~m}$.

Total empty diatoms had a generally different distribution from that of the total full diatoms (Fig. 3). The empty frustules were distributed throughout the upper waters at all sites and were concentrated in the surface waters $(<10 \mathrm{~m})$ in the inner Prydz Bay (Sites 740 and 741) and in the 25-50-m depth range in outer Prydz Bay (Sites 739, 742, and 743). They were observed in very low absolute abundances below $100 \mathrm{~m}$. The total full and empty diatom maxima in the bay over the 17-day period during which the transect was run suggests that they varied with time and location. The shape of the depth profiles of average abundance of the total empty diatoms at the Prydz Bay drill sites differed little from site to site (Figs. 7C and 7D).

In general the empty/full ratios of diatoms increased with depth, except for variability with depth at Site 743 (Fig. 9A). There was much variation with station and depth. At Sites 740 and 741 (inner Prydz Bay) the ratio varied from 0.17 to 0.55 and at Site 739 (outer Prydz Bay) only from 0.23 to 0.33 in the upper $33 \mathrm{~m}$ (above the thermocline), although it increased for the next three depths. The ratio varied from 1.09 to 2.31 at Sites 740 and 741 and from 1.24 to 1.39 at Site 739 below the thermo- 
INTEGRATED CELLS PER SQUARE METER

ABSOLUTE ABUNDANCE OF DOMINANT DIATOMS

PRYDZ BAY DRILL SITES, ODP LEG 119
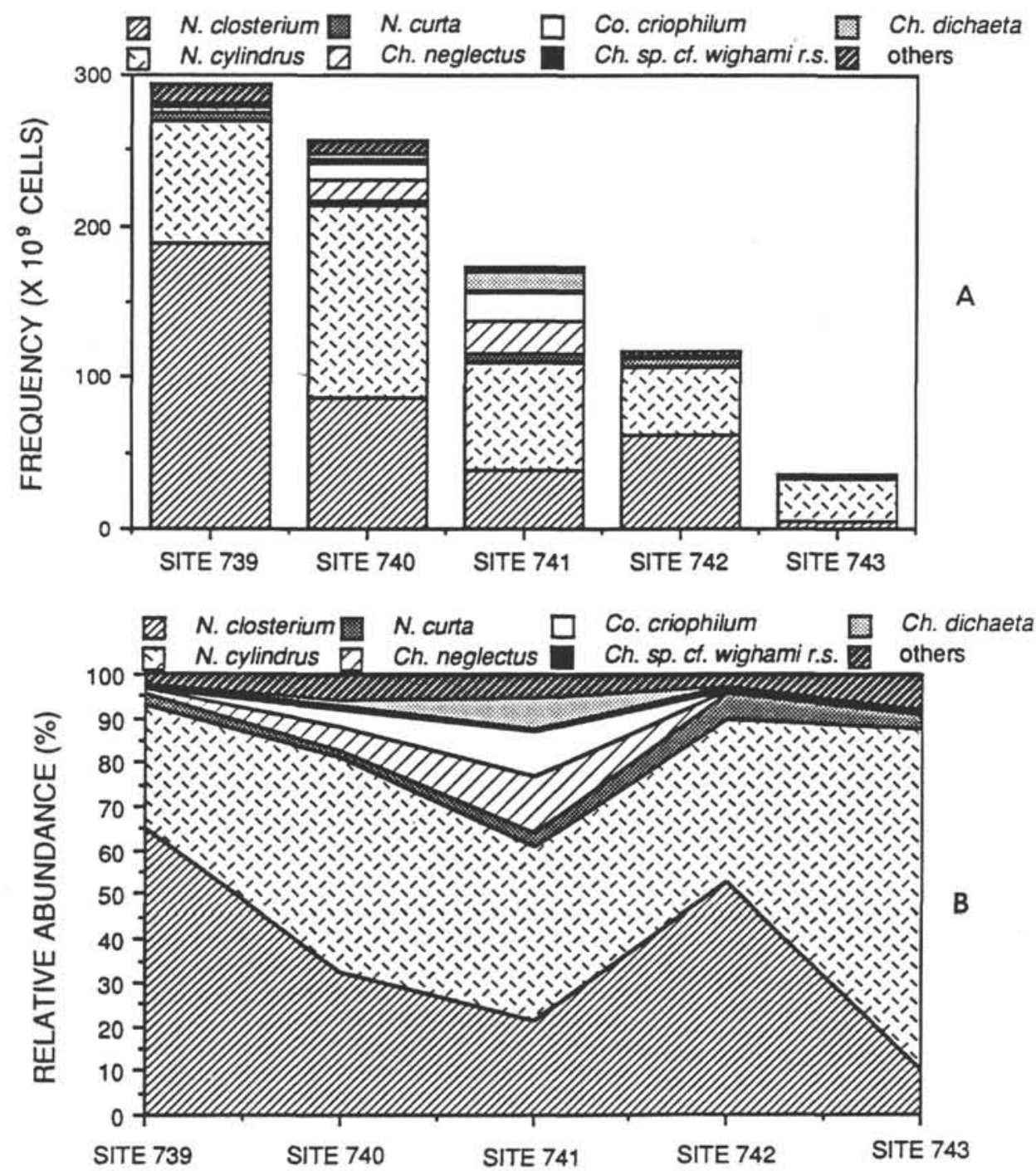

Figure 4. Comparison of integrated absolute abundance (A) and relative abundance (B) of dominant diatom species at Leg 119 Prydz Bay drill sites.

cline, indicating an increase of the empty/full ratio of total diatoms with depth, although a reduction in absolute numbers. The empty cells were abundant in the upper $50 \mathrm{~m}$, but greatly reduced in numbers with depth, indicating suspension or rapid dissolution of the slightly silicified empty frustules in the silicaunsaturated waters (Figs. 7C and 7D).

The ratio of empty thecae to total full cells was smaller at the inner part of Prydz Bay (Sites 740 and 741) and at Site 739 (outer Prydz Bay) than at the two outermost Prydz Bay drill sites, suggesting a healthy and growing population, or possibly low grazing pressure. Conversely, a declining population, or high grazing pressure is suggested at Sites 742 and 743 (Figs. 3 and $9 \mathrm{~A}$ ), where the ratio varied from 0.70 to 3.22 .

The nannoplanktonic diatom Nitzschia cylindrus (full cells) that dominated most of the samples showed a peak in abundance at Site $740\left(3.95 \times 10^{6}\right.$ cells/L) at $10 \mathrm{~m}$ (Fig. 7). Lower numbers $\left(0.343-0.866 \times 10^{6}\right.$ cells $\left./ \mathrm{L}\right)$ were observed in the upper $33 \mathrm{~m}$ at Sites 742 and 743. But integrated cell numbers indicate that $N$. cylindrus (full cells) occurred in highest relative abundances $(>75 \%)$ at Site 743 and lowest relative abundances $(<30 \%)$ at Site 739 (Fig. 4B). Average abundances of the N. cylindrus differed little from site to site, except at Site 740 where the highest numbers were found (Figs. 8A and 8B).

The empty Nitzschia cylindrus and empty total diatoms showed similar patterns of distribution (Figs. 7 and 8). Figure 8 shows the vertical distribution of empty $N$. cylindrus frustules with average abundances in the upper $200 \mathrm{~m}$ for the stations sampled at each drill site. The empty cells were abundant in the upper $33 \mathrm{~m}$ (above the thermocline), but greatly reduced in numbers with depth, indicating rapid dissolution of the slightly silicified empty frustules in the silica-unsaturated waters. The empty/full ratios of $N$. cylindrus were similar to those of total diatoms (Fig. 9). The ratio also increased with depth at all drill sites and was smaller at Sites 739, 740, and 741 than at Sites 742 and 743 (Fig. 9B). At Sites 739,740 , and 741 the ratio varied from 0.37 to 1.36 and at Sites 742 and 743 from 1.65 to 2.80 in the upper 33 $\mathrm{m}$ (above the thermocline). The ratio increased for the next three depths and varied from 1.54 to 4.52 at Sites 739,740 , and 741 
A

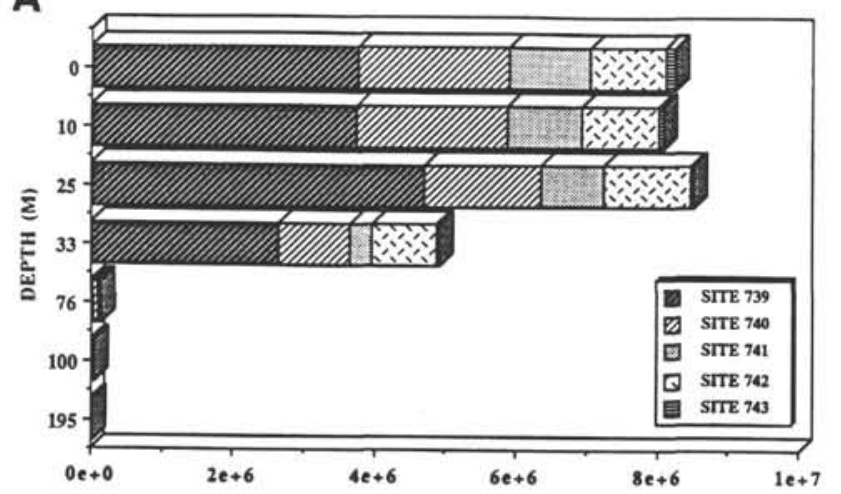

B

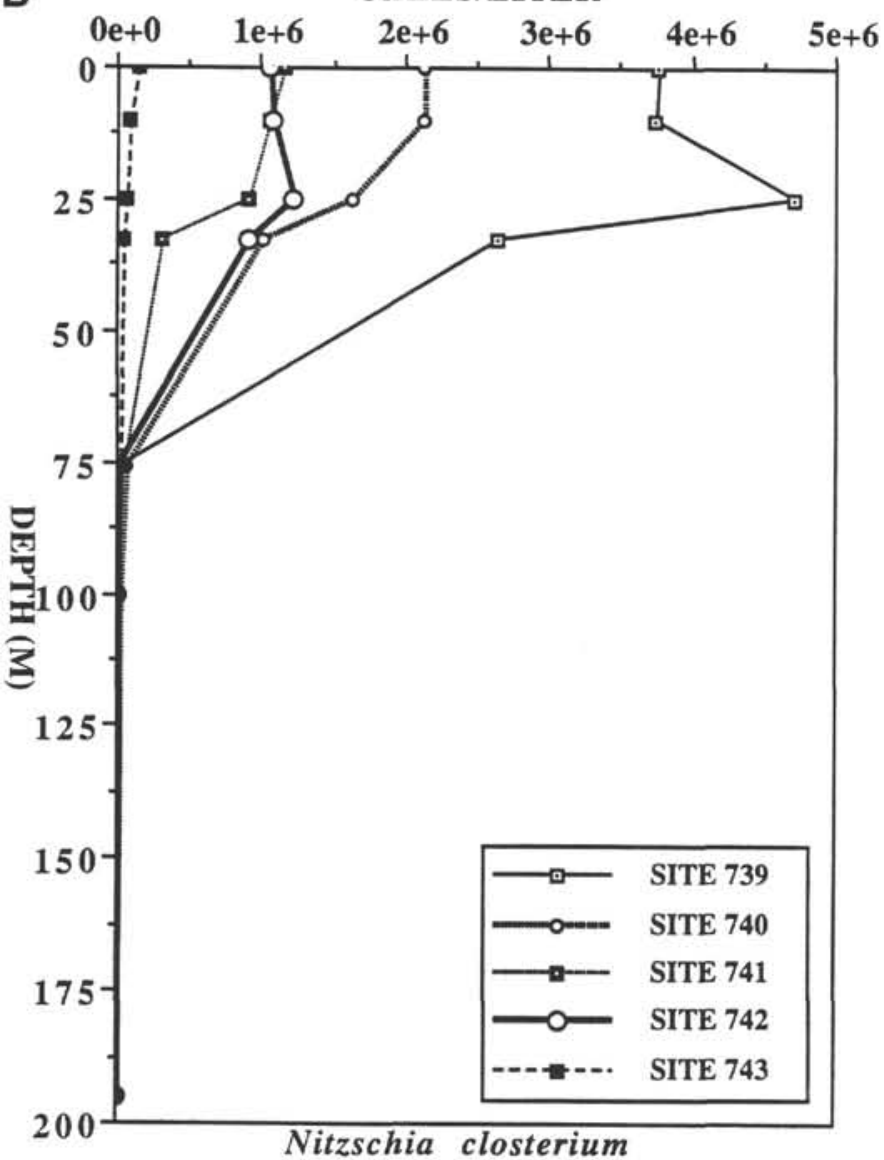

C

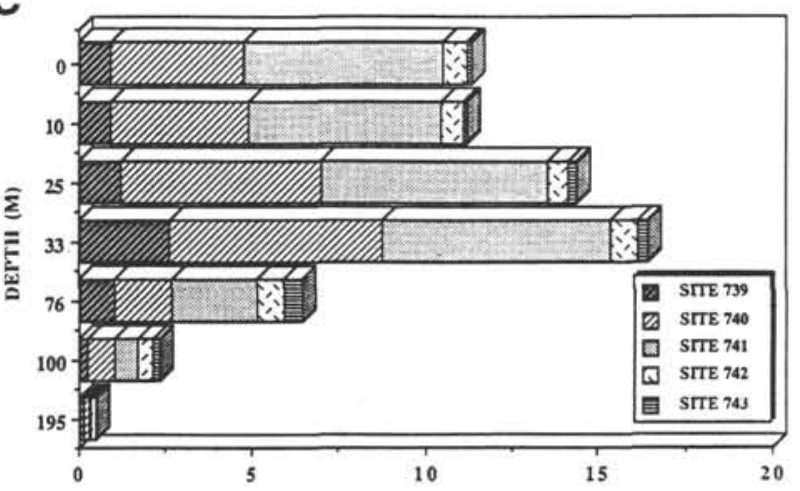

$\mu \mathrm{g} /$ liter

D

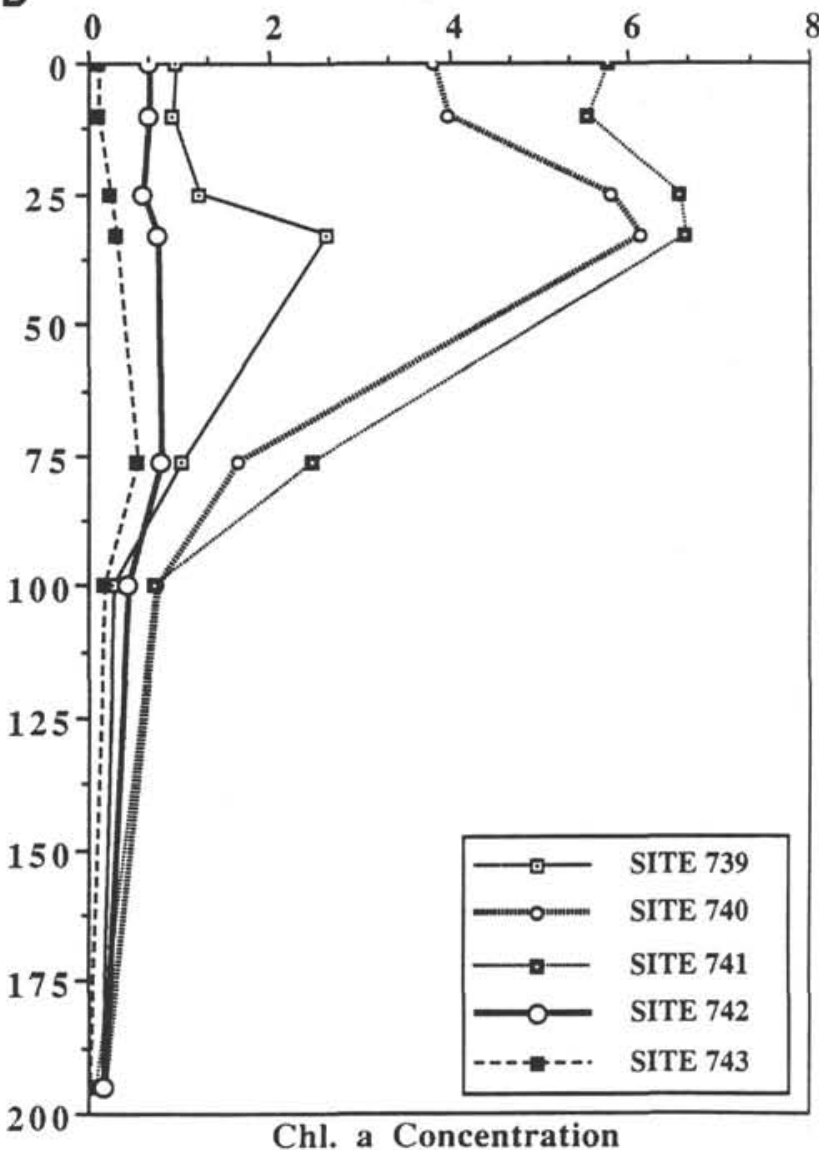

Figure 5. Average abundance with depth. A. Nitzschia closterium, cumulative abundances at all drill sites. B. N. closterium, abundances from discrete water samples. C. Chlorophyll $a$, cumulative concentrations at all drill sites. D. Chlorophyll $a$, concentration from discrete water samples.

and from 2.88 to 9.45 at Sites 742 and 743 , indicating an increase of the empty/full ratio of $N$. cylindrus with depth.

Nitzschia curta was distributed throughout in the bay like the other pennate diatoms, $N$. cylindrus and $N$. closterium. The $N$, curta at Site 741 showed a peak in abundance $\left(0.288 \times 10^{6}\right.$ cells $/ \mathrm{L})$ at $10 \mathrm{~m}$ and another peak in abundance $\left(0.221 \times 10^{6}\right.$ cells $/ \mathrm{L}$ ) at $25 \mathrm{~m}$. Although it was observed in lower abundances at the outer drill sites (Sites 742 and 743), the relative abundance was generally higher than at the inner drill sites (Sites 740 and 741).

The larger-celled diatom species $(>20 \mu \mathrm{m})$ were concentrated in the inner part of Prydz Bay (Sites 740 and 741), with
Chaetoceros dichaeta present in abundances as high as $0.299 \times$ $10^{6}$ cells/L at Site 741 at $10 \mathrm{~m}$, Chaetoceros neglectus with $0.805 \times 10^{6}$ cells $/ \mathrm{L}$ at Site 741 at $25 \mathrm{~m}$, and Corethron criophilum with $0.45 \times 10^{6}$ cells $/ \mathrm{L}$ at Site 741 at $25 \mathrm{~m}$ (Fig. 6). In general, the larger-celled diatom species were in greater abundances in the upper $33 \mathrm{~m}$. They were not as widely distributed as the smaller, more abundant pennate diatoms, indicating better indicators and tracers of local conditions than the numerically dominant small diatoms.

All stations during the occupation of Prydz Bay showed a well-developed summer surface water layer above the seasonal thermohalines (Fig. 2). The temperature profiles (Fig. 2) at CTD 

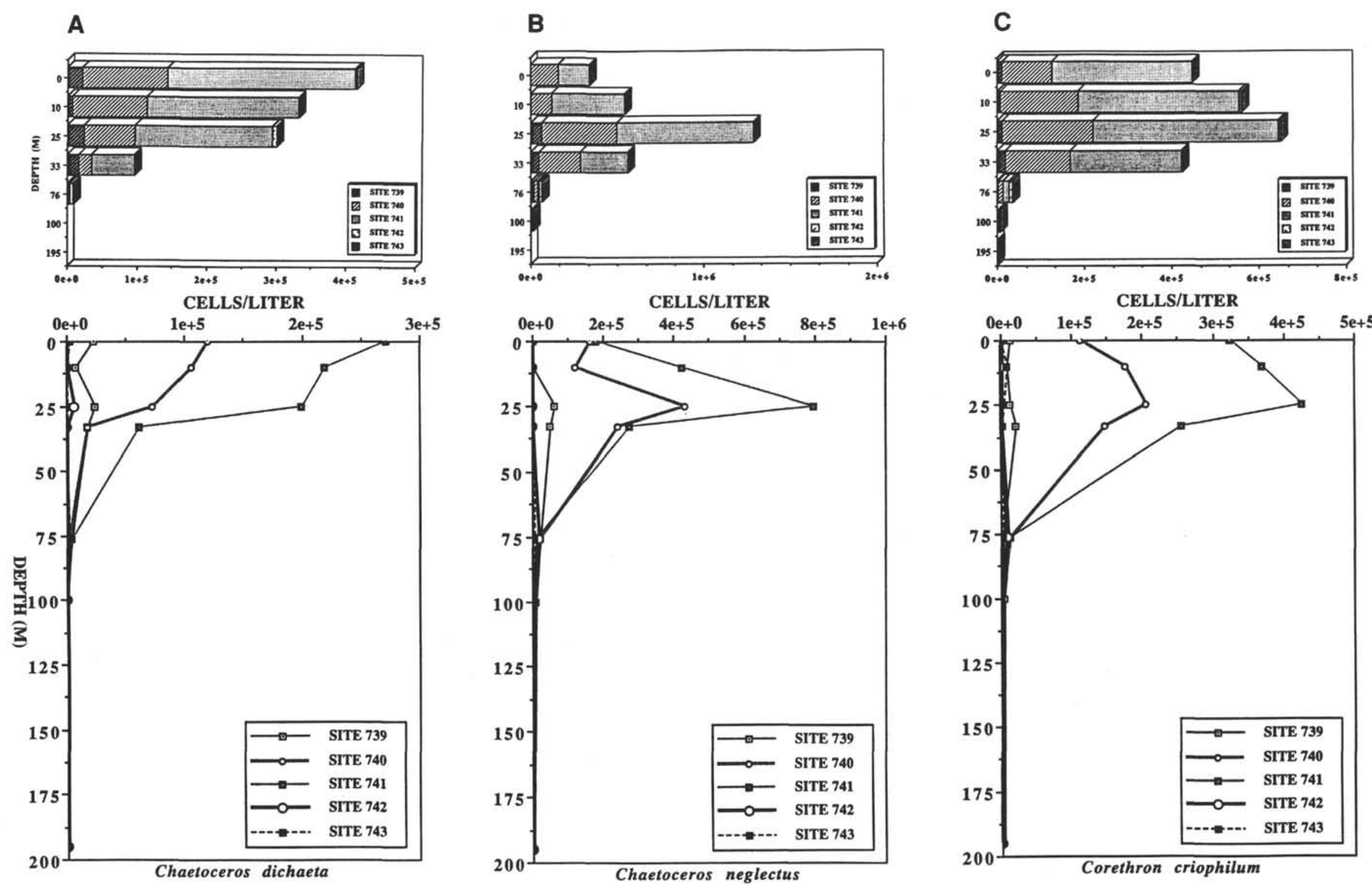

Figure 6. Cumulative abundance and average abundance of larger diatoms with depth from discrete water samples. A. Chaetoceros dichaeta. B. Chaetoceros neglectus. C. Corethron criophilum. 

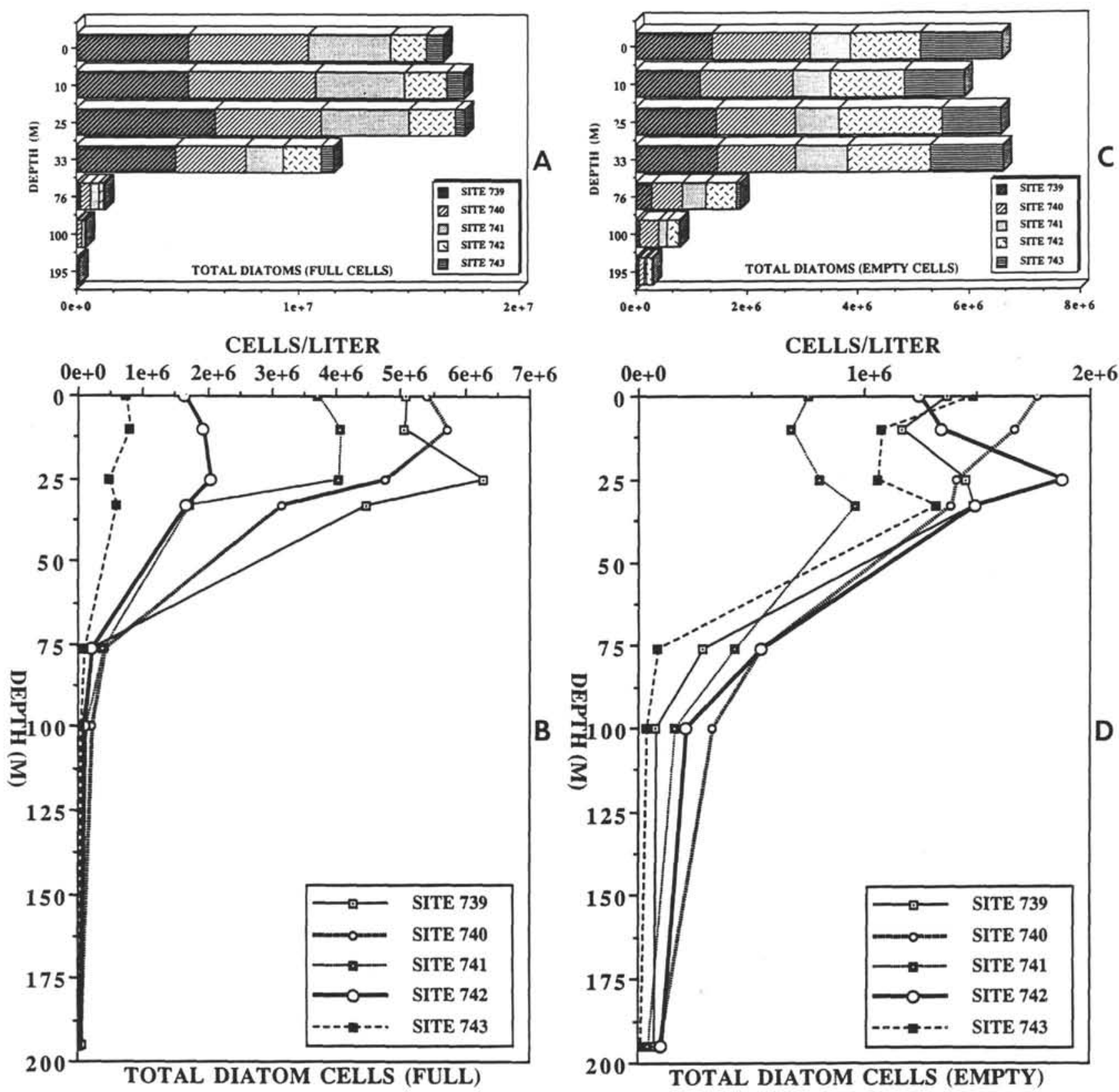

Figure 7. Cumulative and average abundance of total full or living diatoms (A and B) and total empty or dead diatoms (C and D) (cells/L) with depth in the upper $200 \mathrm{~m}$ for stations sampled at each drill site from Maersk Master during ODP Leg 119. A and C. Cumulative abundances at all drill sites. B and D. Separate abundances at each drill site.

stations at the drill sites show the summer surface water above the thermocline was warmer at the inner drill sites (Sites 740 and 741) than at the outer drill sites (Sites 739, 742, and 743). The mixed layer was also shallower at inner drill sites. The mechanics of the evolution and changing of such summer surface layers are not clear; the localized summer heating of surface water and horizontal advection by wind-forcing may play important roles.

The salinity profiles (Fig. 2) show that summer surface water above the halocline was fresher at the outer drill sites (Sites 739, 742 , and 743) than at the inner drill sites. The outer drill sites had been affected by sea ice melt with fresher surface water. The inner drill sites, especially at Site 740 , had no clear halocline, indicating ice-free conditions and no recent ice melting. Thus, the vertical stratification created by summer heating and ice melt and the temporal and spatial variability of the ice condition during the ODP Leg 119 occupation of Prydz Bay for 17 days may be important factors that influenced diatom species composition, abundance, and distribution in the water column assemblages.

\section{Standing Stock}

The standing stock results, as measured by both cell counts and chlorophyll $a$ concentration, and the relative contribution of dominant diatom species to the standing stock are presented in Table 3. The chlorophyll $a$ concentration and the larger-celled diatom species such as Chaetoceros dichaeta, Chaetoceros neglectus, and Corethron criophilum showed similar patterns of distribution. They were concentrated in the upper $50 \mathrm{~m}$ in the inner part of Prydz Bay (Sites 740 and 741).

The chlorophyll $a$ concentration showed a peak in abundance at Site $741(8.34 \mu \mathrm{g} / \mathrm{L})$ at $25 \mathrm{~m}$. At Site 740 (station 7) the peak was found at $33 \mathrm{~m}(7.99 \mu \mathrm{g} / \mathrm{L})$. In the outer part of Prydz 

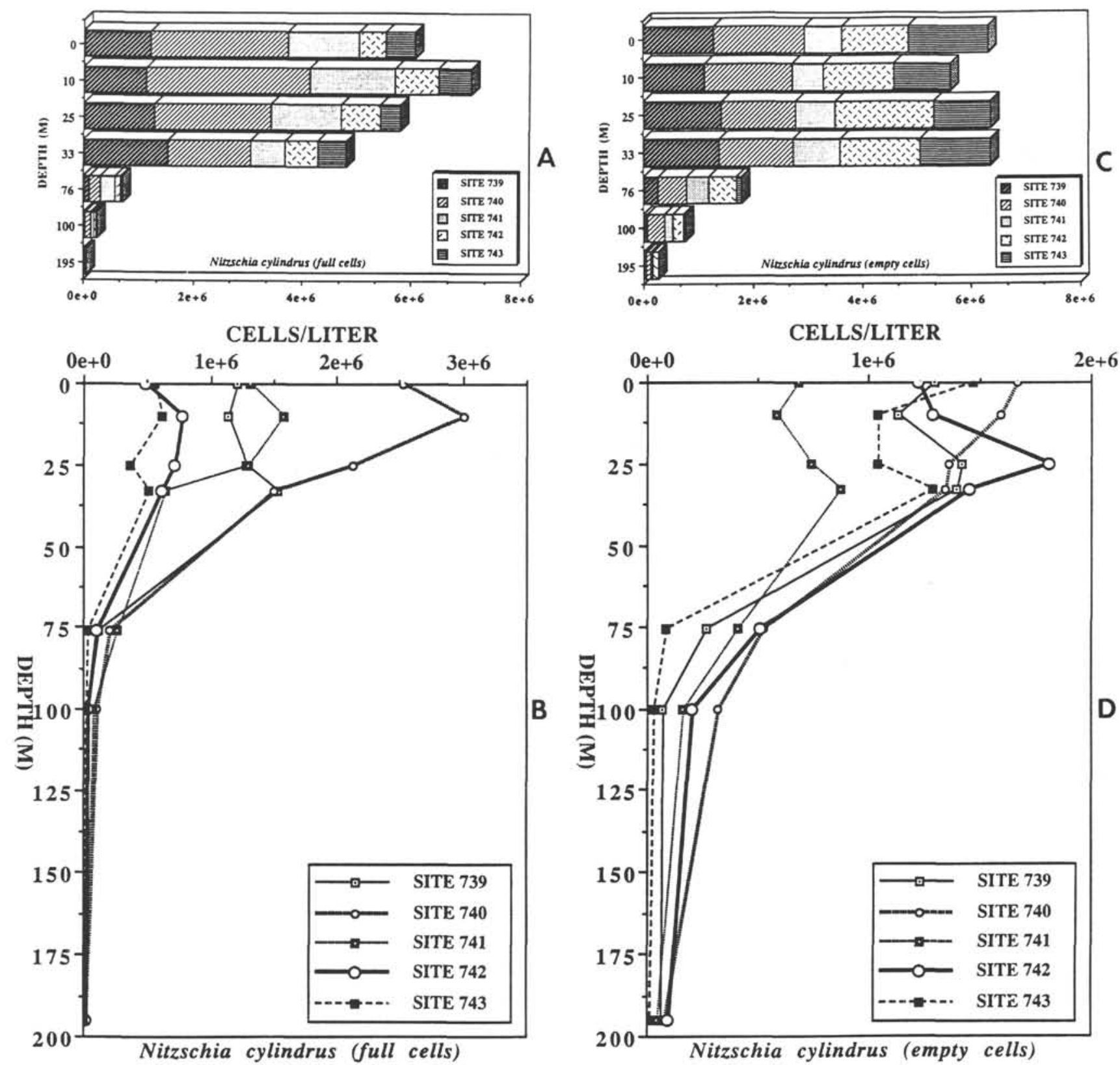

Figure 8. Average abundance of Nitzschia cylindrus (full cells) (A and B) and Nitzschia cylindrus (empty cells) (C and D) (cells/L) with depth in the upper $200 \mathrm{~m}$ for stations sampled at each drill site from Maersk Master during ODP Leg 119. A and C. Cumulative abundances at all drill sites. B and D. Separate abundances at each drill site.

Bay at Site 739 the peak was at $33 \mathrm{~m}(4.18 \mu \mathrm{g} / \mathrm{L})$. The profiles of the average chlorophyll $a$ concentration with depth in the upper $200 \mathrm{~m}$ for stations sampled at each drill site from Maersk Master were also similar to those of the larger-celled diatom species. These were in greater abundance in the inner part of Prydz Bay (Sites 740 and 741) than in the outer part of Prydz Bay (Sites 739, 742, and 743) in the upper $100 \mathrm{~m}$. This suggests that the larger-celled diatoms may contribute to chlorophyll $a$ abundance significantly due to their large cell volumes and high numbers.

Comparisons of distributions of total full diatoms and chlorophyll $a$ of the Prydz Bay stations (Fig. 10) show that diatom cells were observed in high abundances at Sites 739 and 740, but chlorophyll $a$ was concentrated in the inner part (Sites 740 and 741).
Figure 11 shows that chlorophyll $a$ concentration and diatom cell density in the upper $200 \mathrm{~m}$ display positive linear relationships (Site 739, $\mathrm{r}^{2}=0.31, \mathrm{n}=28$ samples; Site $740, \mathrm{r}^{2}=0.67$, $\mathrm{n}=28$ samples; Site 741, $\mathrm{r}^{2}=0.88, \mathrm{n}=14$ samples; Site 742, $\mathrm{r}^{2}=0.38, \mathrm{n}=14$ samples; Site $743, \mathrm{r}^{2}=0.02, \mathrm{n}=14$ samples), indicating more tight coupling between chlorophyll $a$ concentration and diatom cell density in the inner part of Prydz Bay (Sites 740 and 741) than in the outer part of Prydz Bay (Sites 739, 742, and 743).

In an attempt to elucidate the relationships between sample depths and between stations, we subjected the observations to PCA, treating the discrete water samples as cases and the diatom cell abundance and chlorophyll $a$ concentration as variables; seven depths were sampled at all stations. The two plots in Figure 12 are identical, but in Figure 12A, the symbols represent 


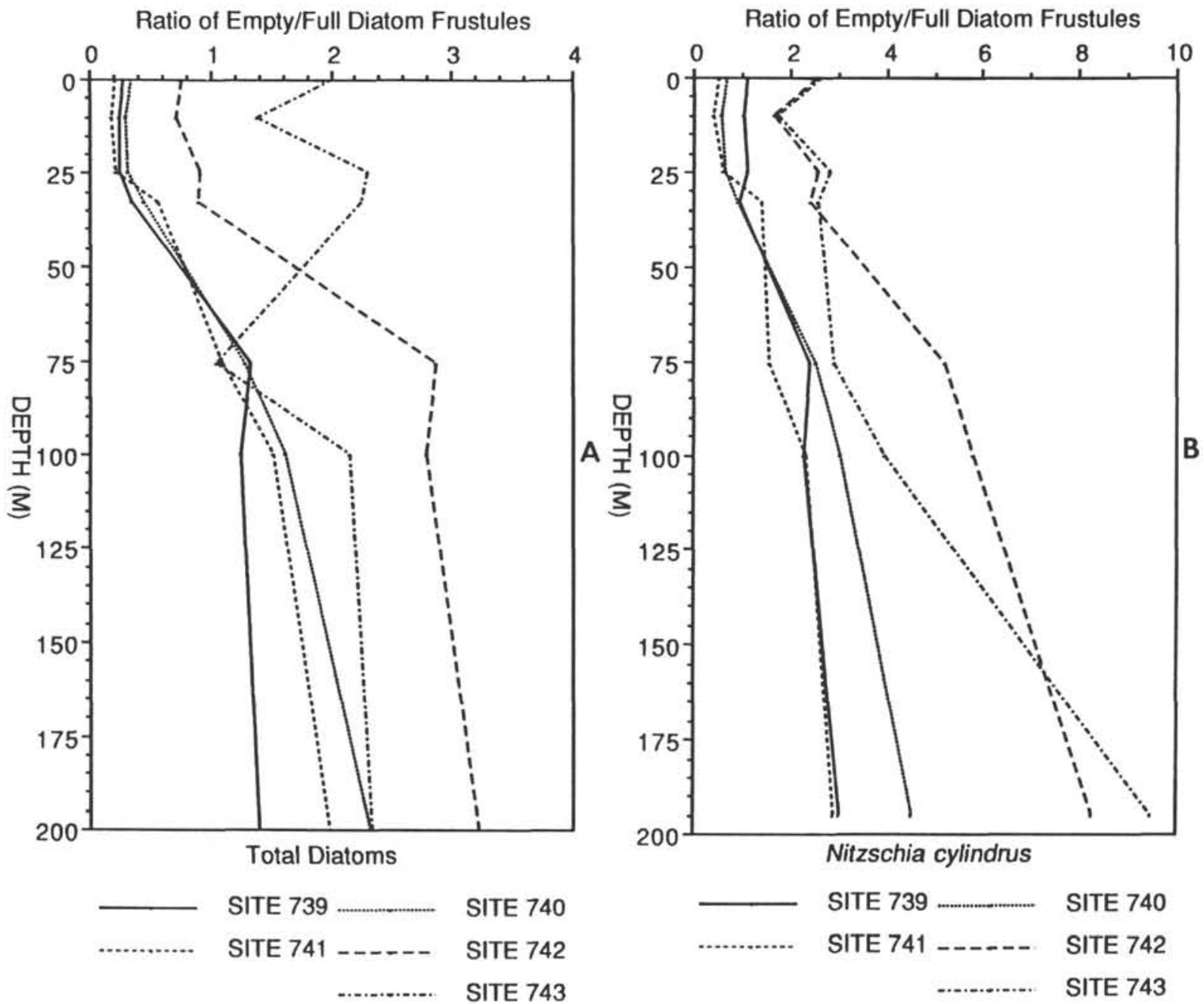

Figure 9. Ratio of empty diatom frustules to full diatom frustules with depth in the upper $200 \mathrm{~m}$. A. Total diatoms. B. Nitzschia cylindrus.

Table 3. Standing stock of planktonic diatoms and the relative contribution of dominant diatom species to diatom cell density and chlorophyll $a$ concentration in water column assemblages in Prydz Bay.

\begin{tabular}{|c|c|c|c|c|c|c|c|c|}
\hline Site & $\begin{array}{l}\text { Date } \\
\text { (1988) }\end{array}$ & $\begin{array}{c}\text { Mean } \\
\text { Chlorophyll } a \\
\left(\mathrm{mg} / \mathrm{m}^{2}\right)\end{array}$ & $\begin{array}{c}\text { Meah } \\
\text { Total diatoms } \\
\left(\times 10^{9} \text { cells } / \mathrm{m}^{2}\right)\end{array}$ & $\begin{array}{l}\text { Nitzschia } \\
\text { cylindrus } \\
\text { ( } \% \text { of total) }\end{array}$ & $\begin{array}{l}\text { Nitzxchia } \\
\text { closterium } \\
\text { (\% of total) }\end{array}$ & $\begin{array}{l}\text { Nitzschia } \\
\text { curta } \\
\text { (\% of total) }\end{array}$ & $\begin{array}{c}\text { Larger-celled } \\
\text { diatoms }(>20 \mu \mathrm{m}) \\
(\% \text { of total) }\end{array}$ & $\begin{array}{c}\text { Other } \\
\text { diatoms } \\
\text { ( } \% \text { of total) }\end{array}$ \\
\hline $\begin{array}{c}739 \\
\text { (Stations 1-4) }\end{array}$ & 18-21 Jan. & 171.75 & 287.87 & 28.0 & 65.3 & 2.4 & 2.71 & 1.59 \\
\hline $\begin{array}{c}740 \\
\text { (Stations 5-8) }\end{array}$ & 22-26 Jan. & 410.25 & 261.75 & 48.5 & 32.8 & 6.5 & 13.7 & 3.47 \\
\hline $\begin{array}{c}741 \\
\text { (Stations 9-10) }\end{array}$ & 27-28 Jan. & 576.5 & 180.10 & 39.3 & 21.5 & 3.44 & 33.7 & 2.06 \\
\hline $\begin{array}{c}742 \\
\text { Stations 11-12) }\end{array}$ & 29 Jan. -1 Feb. & 78.5 & 117.94 & 37.03 & 52.8 & 6.02 & 2.64 & 1.51 \\
\hline $\begin{array}{c}743 \\
\text { (Stations 13-14) }\end{array}$ & 2-3 Feb. & 40.0 & 37.64 & 77.13 & 10.40 & 3.43 & 1.03 & 8.01 \\
\hline
\end{tabular}

the stations from which the samples came, whereas in the Figure 12B plot they represent relative depth. Relative depth 1 at a station is the shallowest.

Three clusters of the samples are apparent. The upper right cluster consists of the near-surface samples (above the thermocline) from Sites 740 and 741 in the inner part of Prydz Bay in the upper $33 \mathrm{~m}$ and corresponds to Cluster 1 (Fig. 13). The lowermost cluster consists of the near-surface samples (above the thermocline) from Site 739, situated in the outer part of Prydz
Bay, in the upper $33 \mathrm{~m}$ and corresponds to Cluster 2 (Fig. 13). The leftmost cluster consists of all samples from Sites 742 and 743 in the upper $200 \mathrm{~m}$ and all the remaining samples below the thermocline from Sites 739, 740, and 741, corresponding to Cluster 3 (Fig. 13).

Each cluster indicates a similar relationship between diatom cell density and chlorophyll $a$ concentration at those stations. Thus, the samples from the Prydz Bay drill sites are not only separated based on depth (above thermocline vs. below thermo- 

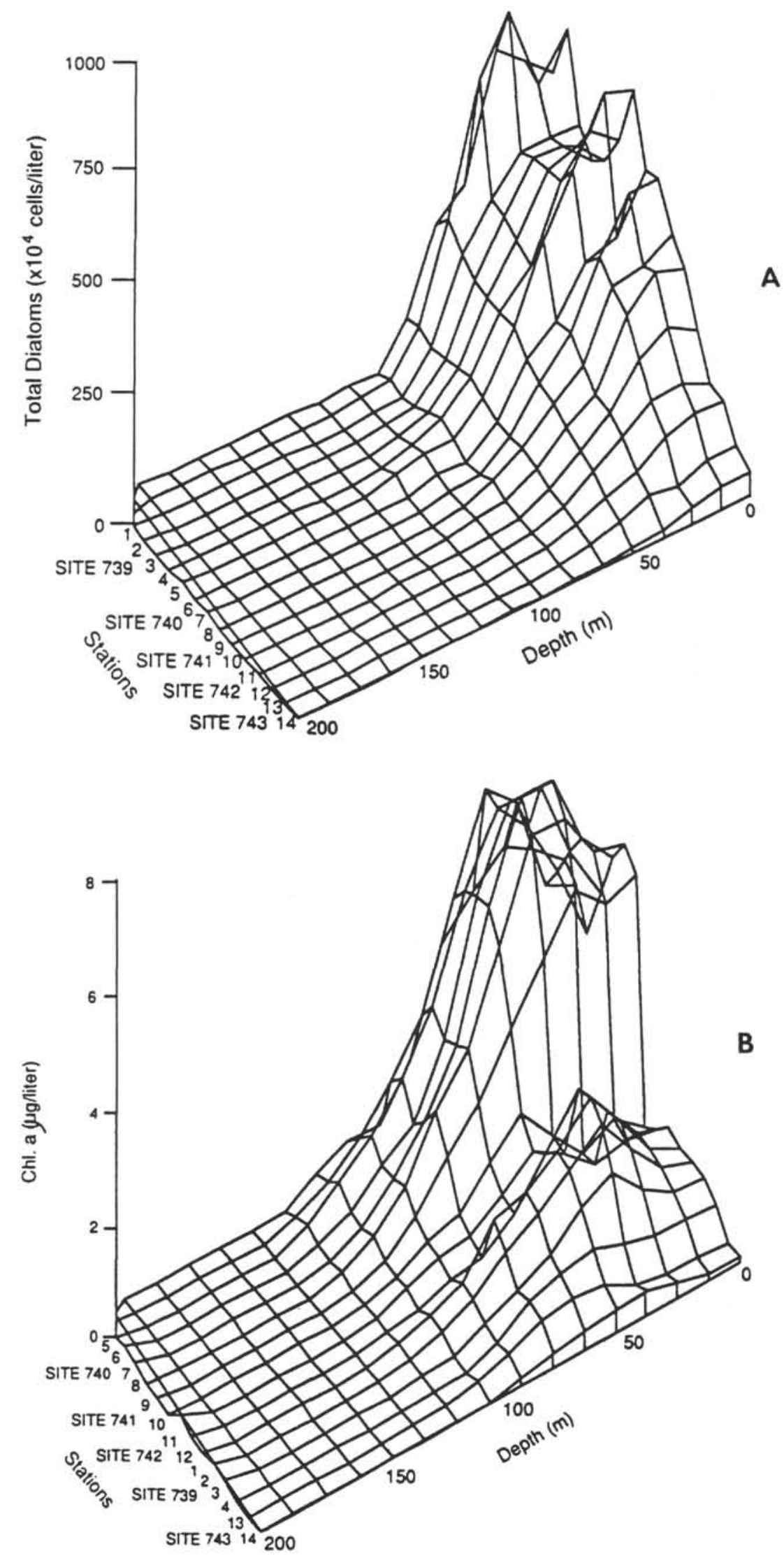

Figure 10. Comparison of distributional patterns of diatom cell density with sites in chronological order (A) and chlorophyll $a$ concentration with sites in geographical sequence on the transect (B) in the upper $200 \mathrm{~m}$ depth along the transect of the Leg 119 Prydz Bay drill sites during an austral summer period (18 January-3 February 1988). 

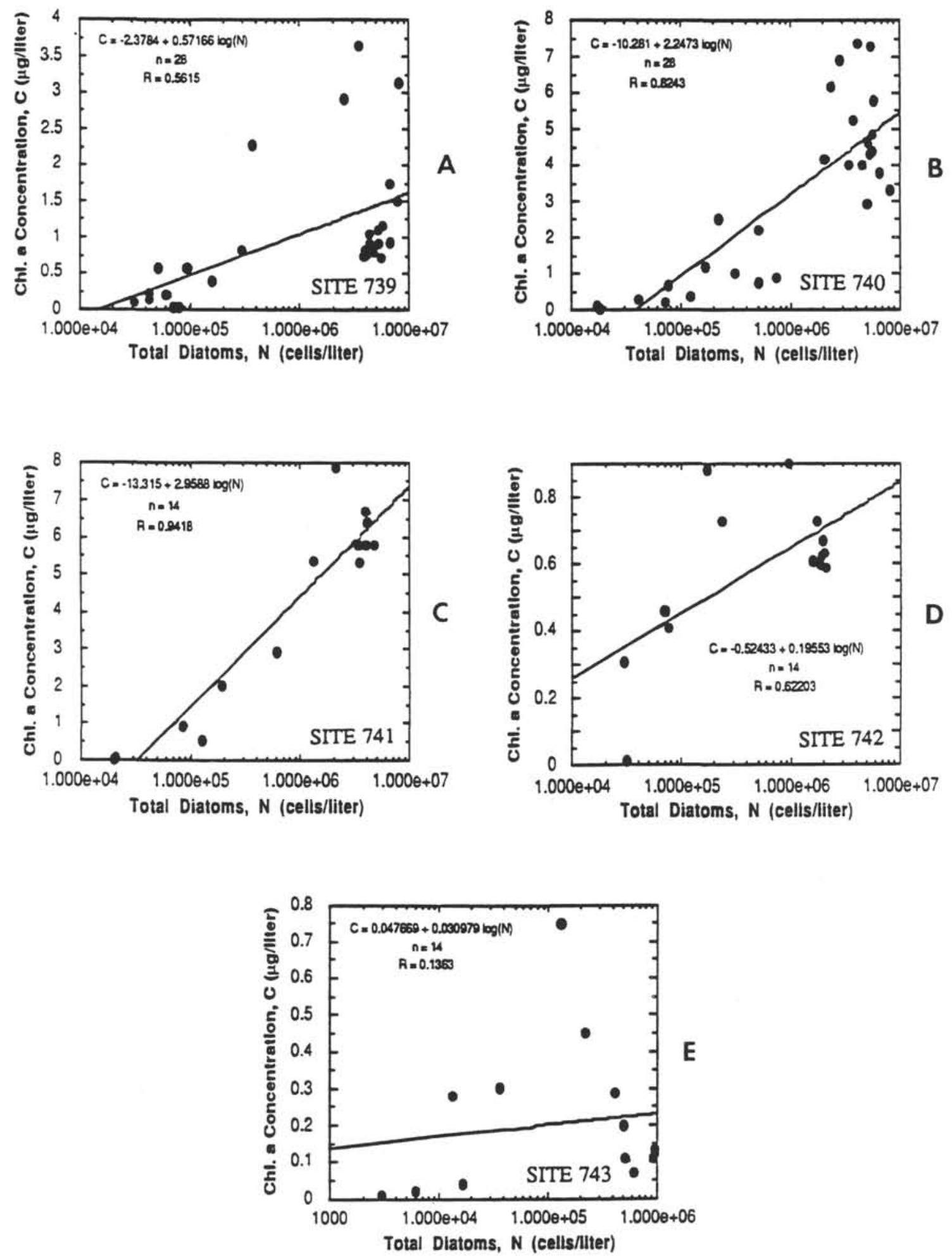

Figure 11. Relationship between chlorophyll $a$ concentration and cell numbers of total full diatoms for stations sampled at each drill site.

cline), but they are separated based on location within the bay (inner Prydz Bay vs. outer Prydz Bay).

In the integrated standing stock (Table 3), in terms of cell numbers and chlorophyll $a$ per $\mathrm{m}^{2}$ from the surface to $200 \mathrm{~m}$ depth, showed that the highest numbers of diatom cells were found at Site 739 , with $287.87 \times 10^{9}$ cells $/ \mathrm{m}^{2}$, and at Sites 740 ,
741,742 , and 743 , with $261.75 \times 10^{9}, 180.10 \times 10^{9}, 117.94 \times$ $10^{9}$, and $37.64 \times 10^{9}$ cells $/ \mathrm{m}^{2}$ in order of average abundance of all stations at each site, respectively. But chlorophyll $a$ concentrations were elevated in the inner part of the bay (Sites 740 and 741). The mean integrated chlorophyll $a$ concentration was highest at Site 741 with $576.5 \mathrm{mg} / \mathrm{m}^{2}$, and at Sites $740,739,742$, and 

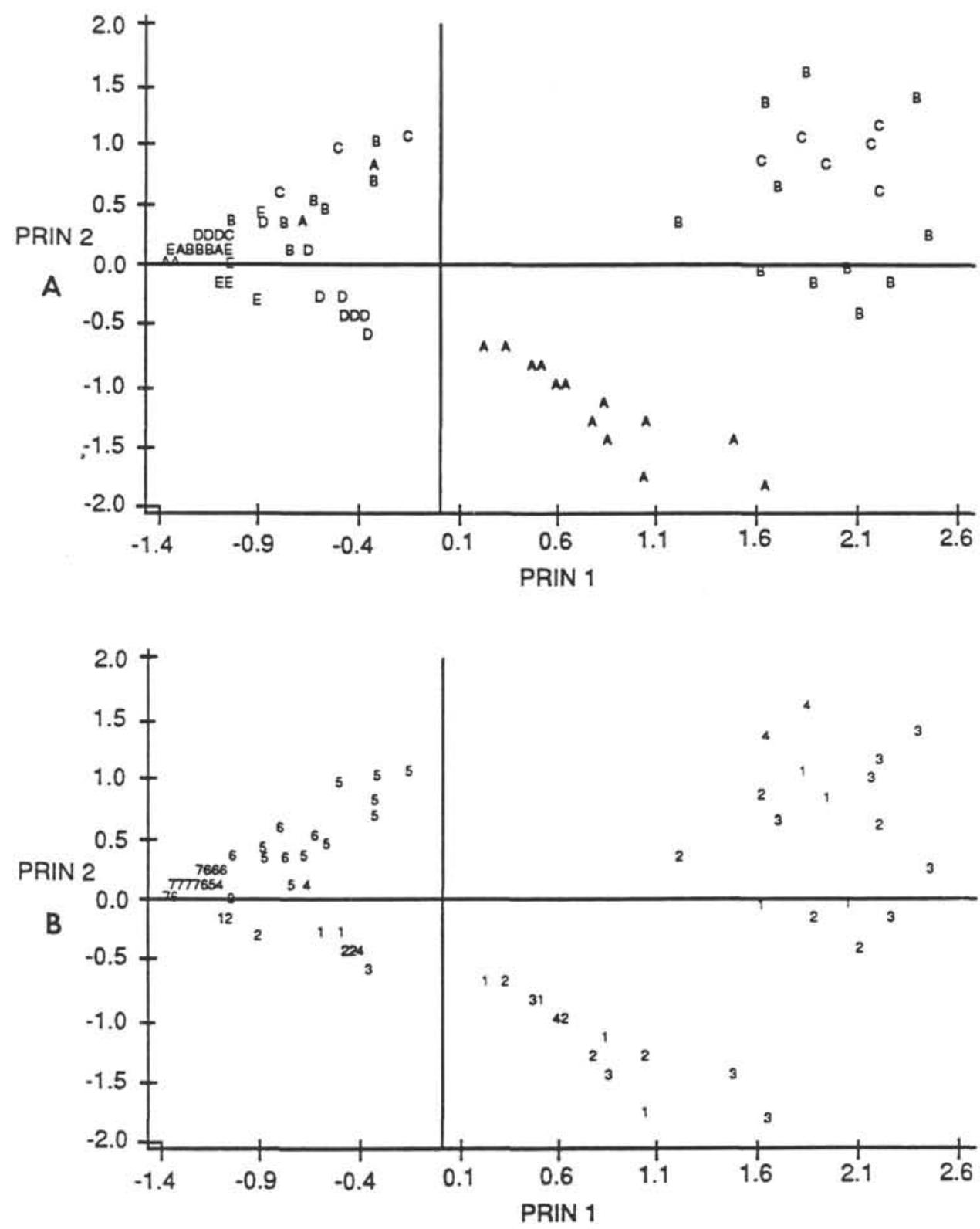

Figure 12. Principal component analysis (PCA) using total full diatom abundance and chlorophyll $a$ concentration as variables. A. A = Site 739 (Stations 1, 2, 3, and 4), outer Prydz Bay; B = Site 740 (Stations 5, 6, 7, and 8), inner Prydz Bay; C = Site 741 (Stations 9 and 10), inner Prydz Bay; $\mathrm{D}=$ Site 742 (Stations 11 and 12), outer Prydz Bay; E = Site 743 (Stations 13 and 14), outer Prydz Bay. B. Symbols represent relative depth. Relative depth 1 is the shallowest sample at a depth.

743 with $410.25,171.75,78.5$, and $40 \mathrm{mg} / \mathrm{m}^{2}$ in order of average concentration of all stations at each site, respectively. Although the numbers of diatom cells were highest at Site 739, the concentration of chlorophyll $a$ was relatively low; in contrast, at Site 741 the concentration of chlorophyll $a$ was highest despite relatively low numbers of diatom cells compared to those at Site 739.

The depths of the chlorophyll and cell maxima are compared in Table 4. Figure 14 shows that the chlorophyll maximum was frequently one or two sample depths deeper in the water column than the cell maximum. Both smaller $(<20 \mu \mathrm{m})$ and larger $(>20 \mu \mathrm{m})$ cells were more abundant in the cell maximum than in the chlorophyll maximum which suggests that the subsurface chlorophyll maximum may simply result from an increased chlorophyll content per cell at the lower light intensities (shade adaption), rather than an increase in the chlorophyll maximum as a result of mass sinking of cells from the surface (Gould, 1988).

\section{DISCUSSION}

The diatom bloom in the water column observed in Prydz Bay during an austral summer period (18 January-3 February 1988), dominated as it was by the nannoplanktonic diatoms Nitzschia cylindrus and $N$. closterium, differs in its species composition from some other blooms reported in previous studies from other Antarctic regions. Historically, the following 


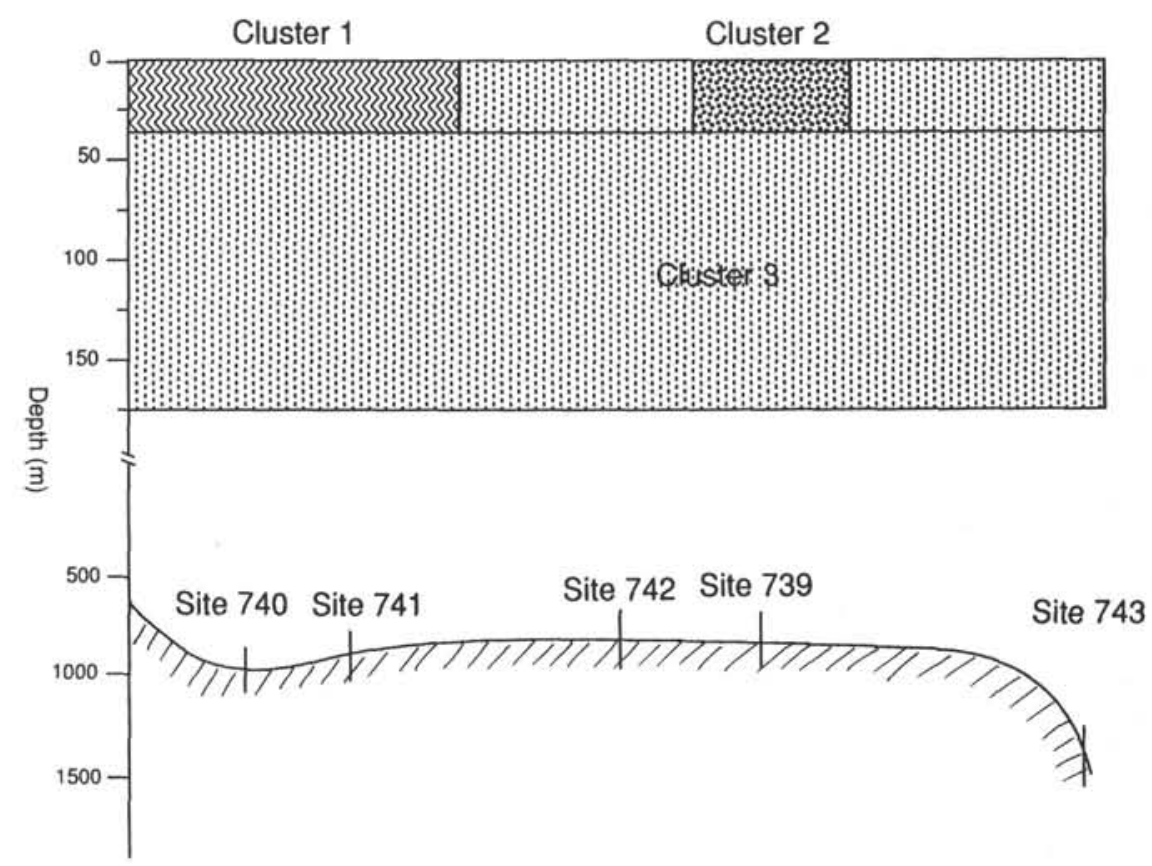

Figure 13. Illustration of the cluster distribution over the Prydz Bay continental shelf after PCA (Fig. 12).

three genera have been reported in large population and blooms near Antarctica: Phaeocystis Lagerheim from the Weddell Sea (Buck and Garrison, 1983; Garrison and Buck, 1985) and the Ross Sea (El-Sayed et al., 1983; Palmisano et al., 1986), Thalassiosira Cleve from the Weddell Sea (El-Sayed, 1971; Hasle et al., 1971), and Nitzschia Hassal from the Ross Sea (Smith and Nelson, 1985; Wilson et al., 1986). Fryxell and Kendrick (1988) found that both Phaeocystis and Thalassiosira dominated the genera in the bloom outside the ice in the Weddell/Scotia Sea. In addition to Nitzschia, other genera such as Chaetoceros Ehrenberg, Corethron Castracane, Rhizosolenia Brightwell, and Tropidoneis Cleve also were abundant at the Prydz Bay drill sites (Sites 740 and 741). Although some authors (Kopczynska et al., 1986; Fryxell, 1986; Fryxell et al., 1987; Weber and ElSayed, 1987; Fryxell et al., in press) have reported the nannoplankton diatom Nitzschia cylindrus as a very important species in the water column, it has not previously been reported as a principal bloom species.

Previous studies using net plankton tows ( $>35-\mu \mathrm{m}$ mesh) and hauls have perhaps given the impression that larger diatoms $(>20 \mu \mathrm{m})$ dominate the Antarctic phytoplankton community. Traditionally, quantitative studies of phytoplankton abundance and distribution have relied on the Utermohl sedimentation method of concentrating cells; the absolute abundances of smaller cells $(<20 \mu \mathrm{m})$, lightly silicified cells, and empty frustules might have been underestimated if the cells remained unsettled or were destroyed by the preservative (Murphy and Haugen, 1985). Kang (1988) found significant differences between the traditionally used sedimentation technique and the HPMA filter technique. In particular, nannoplankton was underestimated, but not netplankton, in the sedimentation method (Kang and Fryxell, 1989). Because the filter itself is used as a part of the mount in the HPMA filter technique, there is no actual loss of cells, and recovery of nannoplankton has been particularly interesting because the problem of distinguishing the trophic mode of nannoplankton is a major concern of biological oceanography. Recent studies have shown the importance of the nannoplanktonic component, in terms of both biomass and primary production, in the Southern Ocean waters as well as in many others (Pome- roy, 1974; Malone, 1980; Hallegraeff, 1981; Hannah and Boney, 1983; Reid, 1983; Hewes et al., 1984; Weber and El-Sayed, 1987; Kang and Fryxell, 1989).

\section{Diatom Distribution Patterns}

Each station was dominated by one or a few species. The bloom at Site 739 was dominated by the long, thin pennate diatom Nitzschia closterium, with the nannoplanktonic diatom $N$. cylindrus the second most common species. $N$. closterium accounted for approximately $65 \%$ of the total number of cells, and $N$. cylindrus was $28 \%$ of the total population within the water column; in contrast, at Site $741 \mathrm{~N}$. cylindrus was the dominant species (approximately $40 \%$ ), while the second most common diatom taxa consisted of the larger-celled diatom taxa ( $>20 \mu \mathrm{m}$ ) such as Chaetoceros dichaeta, Chaetaceros neglectus, Corethron criophilum, etc. (approximately 35\%). At Site 740 $N$. cylindrus was again the dominant species (approximately $48 \%$ ), while the second most abundant diatom species was $N$. closterium (approximately 33\%), and the larger-celled diatom species were approximately $14 \%$ of the total population (Table 3).

The increase in the concentration of the nannoplanktonic diatom Nitzschia cylindrus at Site 740 and the larger-celled diatom species, especially at Site 741 , apparently did contribute to the chlorophyll $a$ concentration. But the dominance of $N$. closterium at Site 739 did not contribute very much to the chlorophyll $a$ concentration, suggesting that the nannoplanktonic diatom $N$. cylindrus and the larger-celled diatom species may be the diatom species that are accounting for most of the chlorophyll $a$ concentration observed in Prydz Bay during an austral summer period. In other words, the larger-celled diatom species and the nannoplanktonic diatom Nitzschia cylindrus may represent a significant biomass source because of their large cell volumes and high numerical abundances, respectively.

Little variation was noted in the relative abundance of the dominant diatom species between Sites 739 and 742 (outer Prydz Bay) and between Sites 740 and 741 (inner Prydz Bay). In order to elucidate the relationships among the stations, in a cluster analysis the stations were treated as cases and the inte- 
Table 4. Comparison of the depths of the chlorophyll and total diatom cell maxima.

\begin{tabular}{|c|c|c|c|}
\hline $\begin{array}{l}\text { Station } \\
\text { drill site }\end{array}$ & $\begin{array}{l}\text { Chlorophyll } \\
\text { maximum }^{\mathrm{a}} \\
(\mu \mathrm{g} / \mathrm{L})\end{array}$ & $\begin{array}{l}\text { Diatom cell } \\
\text { maximum } \\
(\text { cells } / \mathrm{L})\end{array}$ & $\begin{array}{l}\text { Dominant species } \\
\text { in cell } \\
\text { maximum }\end{array}$ \\
\hline $\begin{array}{c}119-1 \\
\text { Site } 739\end{array}$ & $\begin{array}{l}33 \mathrm{~m} \\
(4.81)\end{array}$ & $\begin{array}{c}25 \mathrm{~m} \\
\left(6.81 \times 10^{6}\right)\end{array}$ & $\begin{array}{l}\text { Nitzschia closterium } \\
\text { N. cylindrus } \\
\text { Chaetoceros neglectus }\end{array}$ \\
\hline $\begin{array}{c}119-2 \\
\text { Site } 739\end{array}$ & $\begin{array}{l}33 \mathrm{~m} \\
(3.09)\end{array}$ & $\frac{33 \mathrm{~m}}{\left(8.11 \times 10^{6}\right)}$ & $\begin{array}{l}N . \text { closterium } \\
N . \text { cylindrus } \\
N . \text { curta }\end{array}$ \\
\hline $\begin{array}{c}119-3 \\
\text { Site } 739\end{array}$ & $\begin{array}{l}33 \mathrm{~m} \\
(3.22)\end{array}$ & $\frac{25 \mathrm{~m}}{\left(4.34 \times 10^{6}\right)}$ & $\begin{array}{l}N . \text { closterium } \\
N . \text { cylindrus } \\
N \text {. curta }\end{array}$ \\
\hline $\begin{array}{c}119-4 \\
\text { Site } 739\end{array}$ & $\begin{array}{l}76 \mathrm{~m} \\
(0.83)\end{array}$ & $\begin{array}{l}25 \mathrm{~m} \\
\left(5.50 \times 10^{6}\right)\end{array}$ & $\begin{array}{l}N . \text { closterium } \\
N . \text { cylindrus } \\
N . \text { curta }\end{array}$ \\
\hline $\begin{array}{c}119-5 \\
\text { Site } 740\end{array}$ & $\begin{array}{l}25 \mathrm{~m} \\
(4.84)\end{array}$ & $\begin{array}{l}25 \mathrm{~m} \\
\left(5.68 \times 10^{6}\right)\end{array}$ & $\begin{array}{l}N . \text { cylindrus } \\
N \text {. closterium } \\
\text { Chaetoceros neglectus } \\
\text { Corethron criophilum }\end{array}$ \\
\hline $\begin{array}{c}119-6 \\
\text { Site } 740\end{array}$ & $\begin{array}{l}33 \mathrm{~m} \\
(6.80)\end{array}$ & $\begin{array}{c}10 \mathrm{~m} \\
\left(8.38 \times 10^{6}\right)\end{array}$ & $\begin{array}{l}N . \text { cylindrus } \\
N . \text { closterium } \\
N \text {. curta } \\
\text { Corethron criophilum }\end{array}$ \\
\hline $\begin{array}{c}119-7 \\
\text { Site } 740\end{array}$ & $\begin{array}{l}33 \mathrm{~m} \\
(7.99)\end{array}$ & $\stackrel{0 \mathrm{~m}}{\left(5.17 \times 10^{6}\right)}$ & $\begin{array}{l}\text { N. cylindrus } \\
\text { N. closterium } \\
\text { Chaetoceros neglectus } \\
\text { N. curta } \\
\text { Chaetoceros dichaeta }\end{array}$ \\
\hline $\begin{array}{c}119-8 \\
\text { Site } 740\end{array}$ & $\begin{array}{l}25 \mathrm{~m} \\
(6.60)\end{array}$ & $\begin{array}{c}10 \mathrm{~m} \\
\left(5.70 \times 10^{6}\right)\end{array}$ & $\begin{array}{l}\text { N. cylindrus } \\
N \text {. closterium } \\
\text { Chaetoceros neglectus } \\
\text { Corethron criophilum } \\
\text { Chaetoceros diachaeta }\end{array}$ \\
\hline $\begin{array}{c}119-9 \\
\text { Site } 741\end{array}$ & $\begin{array}{l}33 \mathrm{~m} \\
(7.89)\end{array}$ & $\frac{0 \mathrm{~m}}{\left(4.01 \times 10^{6}\right)}$ & $\begin{array}{l}\text { N. cylindrus } \\
N \text {. closterium } \\
\text { Chaetoceros neglectus } \\
\text { Corethron criophilum } \\
\text { Chaetoceros dichaeta }\end{array}$ \\
\hline $\begin{array}{l}119-10 \\
\text { Site } 741\end{array}$ & $\begin{array}{l}25 \mathrm{~m} \\
(8.34)\end{array}$ & $\begin{array}{c}10 \mathrm{~m} \\
\left(4.66 \times 10^{6}\right)\end{array}$ & $\begin{array}{l}N . \text { cylindrus } \\
N \text {. closterium } \\
\text { Corethron criophlim } \\
\text { Chaetoceros neglectus } \\
N . \text { curta }\end{array}$ \\
\hline $\begin{array}{c}119-11 \\
\text { Site } 742\end{array}$ & $\begin{array}{l}76 \mathrm{~m} \\
(0.56)\end{array}$ & $\begin{array}{c}33 \mathrm{~m} \\
\left(2.14 \times 10^{6}\right)\end{array}$ & $\begin{array}{l}N . \text { closterium } \\
N . \text { curta } \\
N \text {. cylindrus }\end{array}$ \\
\hline $\begin{array}{l}119-12 \\
\text { Site } 742\end{array}$ & $\begin{array}{l}76 \mathrm{~m} \\
(0.89)\end{array}$ & $\begin{array}{c}25 \mathrm{~m} \\
\left(1.96 \times 10^{6}\right)\end{array}$ & $\begin{array}{l}\text { N. closterium } \\
N . \text { cylindrus } \\
N . \text { curta }\end{array}$ \\
\hline $\begin{array}{l}119-13 \\
\text { Site } 743\end{array}$ & $\begin{array}{l}76 \mathrm{~m} \\
(0.75)\end{array}$ & $\begin{array}{l}0 \mathrm{~m} \\
\left(9.49 \times 10^{5}\right)\end{array}$ & $\begin{array}{l}N . \text { cylindrus } \\
N . \text { closterium } \\
N . \text { curta }\end{array}$ \\
\hline $\begin{array}{l}119-14 \\
\text { Site } 743\end{array}$ & $\begin{array}{l}33 \mathrm{~m} \\
(0.45)\end{array}$ & $\begin{array}{c}10 \mathrm{~m} \\
\left(6.22 \times 10^{5}\right)\end{array}$ & $\begin{array}{l}N . \text { cylindrus } \\
N \text {. closterium } \\
N . \text { curta }\end{array}$ \\
\hline
\end{tabular}

${ }^{a}$ Determined from discrete chlorophyll samples (samples for which cell abundances were determined).

grated absolute abundances (cells $/ \mathrm{m}^{2}$ ) of different taxa as variables (Table 5).

The station clustering was done with different kinds of variables. In Figure 15A the cluster analysis was performed by using nine variables: eight dominant diatom species including Nitzschia cylindrus, $N$. closterium, N. curta, Chaetoceros dichaeta, Chaetoceros neglectus, Chaetoceros sp. cf. wighamii, Corethron criophilum, and Tropidoneis sp. cf. vanheurckii and total full diatom cells.
When the cluster analysis was performed using the nine variables (Fig. 15A), two major groups were delineated: the inner Prydz Bay stations and the outer Prydz Bay stations with an anomalous station (Site 739, station 1) in the outer part of Prydz. Bay. Fig. 2 shows that at station 1 of Site 739 the depth profiles of temperature and salinity show a less-marked thermocline and halocline than those of the other stations at that site. The changing local conditions may have lead to a different diatom species composition and abundance. Table 5 shows that at Site 739 (station 1) the larger-celled diatom species such as Chaetoceros dichaeta, $C$. sp. cf. wighamii, Coretheron criophilum, and Tropidoneis sp. cf. vanheurckii were in higher abundance than at the other three stations of Site 739. Within the first group, Site 740 stations (E, H, and G) separated from the Site 741 stations (I and J). Within the second group, Site 739 stations (C and D) were similar to Site 742 stations ( $K$ and $L$ ) and separated somewhat from Site 743 stations ( $M$ and $N$ ).

Although larger-celled phytoplankton $(>20 \mu \mathrm{m})$ are generally found at lower concentrations than the numerically dominant smaller-celled phytoplankton in the Southern Ocean waters, they may be considered as a significant biomass source due to their large cell volumes. In an attempt to clarify whether or not the larger-celled diatom species are better indicators and tracers of coastal water masses than the smaller-celled diatom species, the station clustering was done by using only largercelled diatom species (Chaetoceros dichaeta, Chaetoceros neglectus, Chaetoceros sp. cf. wighamii, Corethron criophilum, and Tropidoneis sp. $\mathrm{cf}$. vanheurckii; Fig. 15B) and using only the smaller-celled pennate diatom species (Nitzschia cylindrus, $N$. closterium, and N. curta; Fig. 15C).

When only larger-celled diatom species were included in the analysis (Fig. 15B), two major groups were again delineated when nine variables were used. Clearer geographical clustering of inner stations and outer stations of Prydz Bay was observed using only larger-celled diatom species variables. Within the first group, Site 742 stations (K and L) were similar to the Site 739 stations (A, B, C, and D) and Site 743 stations (M and N) situated in the outer part of Prydz Bay. Within the second group, Site 740 stations (E, F, G, and H) were similar to Site 741 stations ( $\mathrm{I}$ and $\mathrm{J}$ ) located in the inner part of Prydz Bay.

When only smaller-celled diatom species were used in the analysis (Fig. 15C), the results were different from those with only larger-celled diatom species. Stations from inner and outer Prydz Bay drill sites intermingled without clear separation. In this case the larger-celled diatom species appeared to be better indicators and tracers of local conditions than the smaller-celled diatom species, which showed similar abundances and ubiquitous distributions and not disjunct changes.

The two spatial distributional patterns of dominant diatom species at the Prydz Bay drill sites may be affected by the differences in hydrographic conditions, nutrient concentrations, surface irradiance, vertical stability, and biological features in different geographical locations. The different physical and biological processes operating in the bay may enable different diatom species to dominate in the two regions (inner Prydz Bay and outer Prydz Bay). The vertical stratification created by summer heating and ice melt and the temporal and spatial variability of the ice condition during the ODP Leg 119 occupation of Prydz Bay for 17 days may be major factors that especially influence diatom species composition, abundance, and distribution in water column assemblages.

The abundance and relative dominance of the different diatom species underwent sequential change in the short growing season. During four days at the first drill site (Site 739) in outer Prydz Bay Nitzschia closterium was the dominant species, accounting for $55 \%-77 \%$ in relative abundance. In contrast at the inner drill sites (Sites 740 and 741), the dominant diatom species $N$. cylindrus accounted for $39 \%-55 \%$, accompanied by a higher 

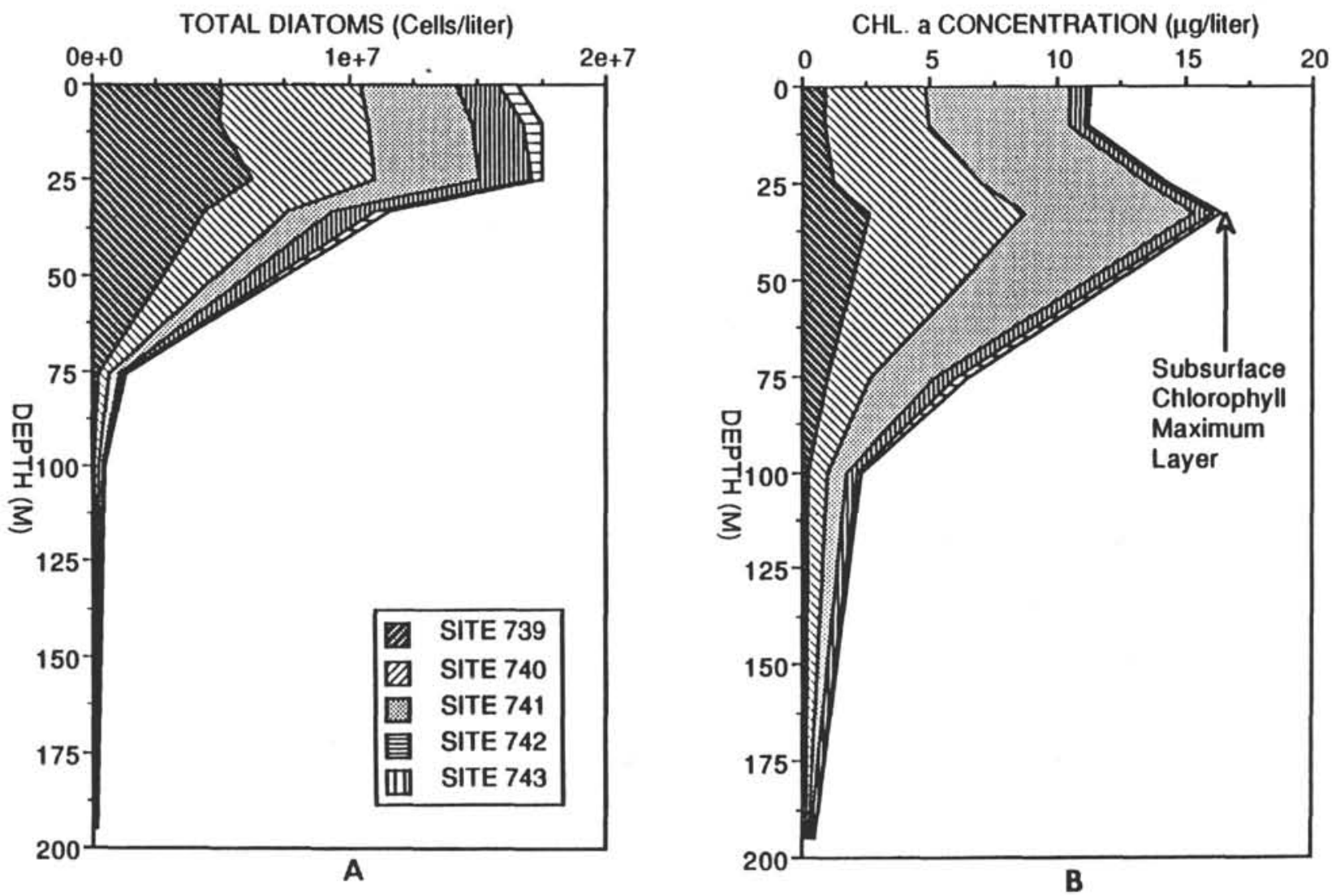

Figure 14. Comparison of average cell numbers of total full diatoms (A) and chlorophyll $a$ concentration (B) in the upper $200 \mathrm{~m}$ for stations sampled at all drill sites from Maersk Master (ODP Leg 119).

relative abundance of larger-celled diatom species (14\%-34\%) than in the outer part of Prydz Bay.

Figures on the pack ice distribution and coverage for the Prydz Bay section of the Southern Ocean from November 1987 to February 1988 from the National Oceanic and Atmospheric Administration (NOAA)-09, NOAA-10, and Defense Meteorological Satellite Program (DMSP) satellite imagery by the NavyNOAA Joint Ice Center in Suitland, Maryland, show longer icefree periods in the inner part of Prydz Bay than in the outer part. The inner Prydz Bay already had a ice-free period from the middle of December 1987, but the outer bay was affected by the pack ice until the middle of January 1988.

Nitzschia closterium dominated at pack ice-affected drill sites (Sites 739 and 742). As time went by, the dominance of the ice-related diatom $N$. closterium might have been changed to that of $N$. cylindrus during the early stages in the ice-free period. While these small pennate diatom species continued to dominate and were distributed widely throughout the bay during the ice-free period, larger-celled diatom species with highest concentrations observed near shore (Sites 740 and 741) could dominate during the later stages in the ice-free period. The dominant diatom species undergoing sequential change in the short growing season may vary regionally, influenced by watermass type, temporal and spatial variability of ice condition, and location and composition of the initial species inoculated from the ice melt.

\section{CONCLUSIONS}

Diversity of species was very low, with a single dominant species (Nitzschia cylindrus or $N$. closterium) accounting for $39 \%-$ $77 \%$ in relative abundance of samples counted at any one station.
The highest numbers of full diatom cells were found at Site 739 , followed by Sites $740,741,742$, and 743 in order of average abundance, respectively, and sequential in the short growing season. Empty cells have the same order of abundance in general, although they are less in grand totals.

Two different distributional patterns were observed in Prydz Bay during an austral summer period. The small pennate diatoms Nitzschia cylindrus, $N$. closterium, and $N$. curta dominated in the water column assemblages at all Prydz Bay drill sites and were distributed throughout the waters in the bay, whereas the larger-celled diatom species Chaetoceros dichaeta, Chaetoceros neglectus, Corethron criophilum, etc., dominated only the inner part of Prydz Bay.

The smaller-celled diatom species and total diatom cell density showed similar patterns of distribution, while the largercelled diatom species and chlorophyll $a$ concentration showed similar patterns.

Diatom cell maxima were located slightly above the thermocline while chlorophyll maxima were located in the thermocline, slightly below the diatom cell maxima. In general, there was a strong relationship between the physical structure (depth profiles of thermohalines) and biological structure (depth profiles of diatom abundances). The vertical stratification created by summer heating and ice melt was a major factor that influenced vertical distribution of diatom cells.

Empty cells were abundant in the upper $50 \mathrm{~m}$, but greatly reduced in numbers with depth, indicating dissolution of the lightly silicified empty frustules in the silica-undersaturated waters. The ratio of empty/full diatoms increased with depth, however.

Principal component analysis using diatom cell density (cells/ L) and chlorophyll $a$ concentration $(\mu \mathrm{g} / \mathrm{L})$ from discrete water 
Table 5. Integrated absolute abundances $\left(\times 10^{9}\right.$ cells $\left./ \mathrm{m}^{2}\right)$.

\begin{tabular}{|c|c|c|c|c|c|c|c|c|c|c|c|c|c|c|c|}
\hline \multirow[b]{2}{*}{ Species } & \multirow[b]{2}{*}{ Stations } & \multicolumn{4}{|c|}{ Site 739} & \multicolumn{4}{|c|}{ Site 740} & \multicolumn{2}{|c|}{ Site 741} & \multicolumn{2}{|c|}{ Site 742} & \multicolumn{2}{|c|}{ Site 743} \\
\hline & & {$[1$} & 2 & 3 & 4] & [5 & 6 & 7 & 8] & {$[9$} & 10] & {$[11$} & 12] & {$[13$} & 14] \\
\hline${ }^{\mathrm{a}}$ Chaetoceros dichaeta & & 1.72 & 0.65 & 0.74 & 0.18 & 1.71 & 3.37 & 4.72 & 2.95 & 10.62 & 5.55 & 0.08 & 0.00 & 0.00 & 0.10 \\
\hline${ }^{\mathrm{a}} \mathrm{C}$. neglectus & & 2.73 & 3.20 & 3.45 & 2.22 & 15.48 & 13.12 & 17.94 & 12.84 & 23.82 & 21.20 & 0.12 & 1.08 & 0.27 & 0.04 \\
\hline${ }^{\mathrm{a}}$ C. sp. cf. wighamii & & 1.82 & 0.09 & 0.31 & 0.34 & 3.11 & 4.49 & 2.63 & 2.76 & 1.05 & 1.54 & 1.31 & 0.84 & 0.08 & 0.00 \\
\hline${ }^{\mathrm{a}}$ Corethron criophilum & & 1.30 & 0.52 & 0.40 & 0.90 & 8.93 & 10.82 & 8.07 & 9.91 & 19.71 & 16.68 & 0.19 & 0.60 & 0.14 & 0.33 \\
\hline${ }^{\mathrm{b}}$ Nitzschia closterium & & 165.43 & 320.11 & 108.40 & 181.63 & 71.97 & 167.05 & 57.54 & 66.55 & 39.32 & 38.10 & 67.59 & 51.68 & 5.69 & 2.14 \\
\hline${ }^{\mathrm{b}} N$. curta & & 3.95 & 7.60 & 10.19 & 8.37 & 1.66 & 8.82 & 2.95 & 2.93 & 4.93 & 7.46 & 8.27 & 4.86 & 1.63 & 0.94 \\
\hline${ }^{b} N$. cylindrus & & 87.58 & 76.39 & 67.88 & 84.05 & 19.73 & 165.90 & 86.58 & 131.55 & 73.68 & 68.17 & 44.59 & 41.84 & 39.67 & 18.33 \\
\hline $\begin{array}{l}{ }^{\mathrm{a}} \text { Tropidoneis } \\
\text { sp. cf. vanheurickii }\end{array}$ & & 1.20 & 0.29 & 0.29 & 0.09 & 0.14 & 0.00 & 1.01 & 0.68 & 0.98 & 1.13 & 0.38 & 0.19 & 0.00 & 0.02 \\
\hline Total diatoms & & 274.55 & 413.44 & 196.38 & 280.41 & 238.62 & 399.57 & 190.88 & 239.84 & 188.92 & 171.28 & 125.01 & 103.81 & 51.98 & 23.29 \\
\hline
\end{tabular}

Note: All variables used for Figure 15A cluster analysis.

b Variables used for Figure 15B cluster analysis.
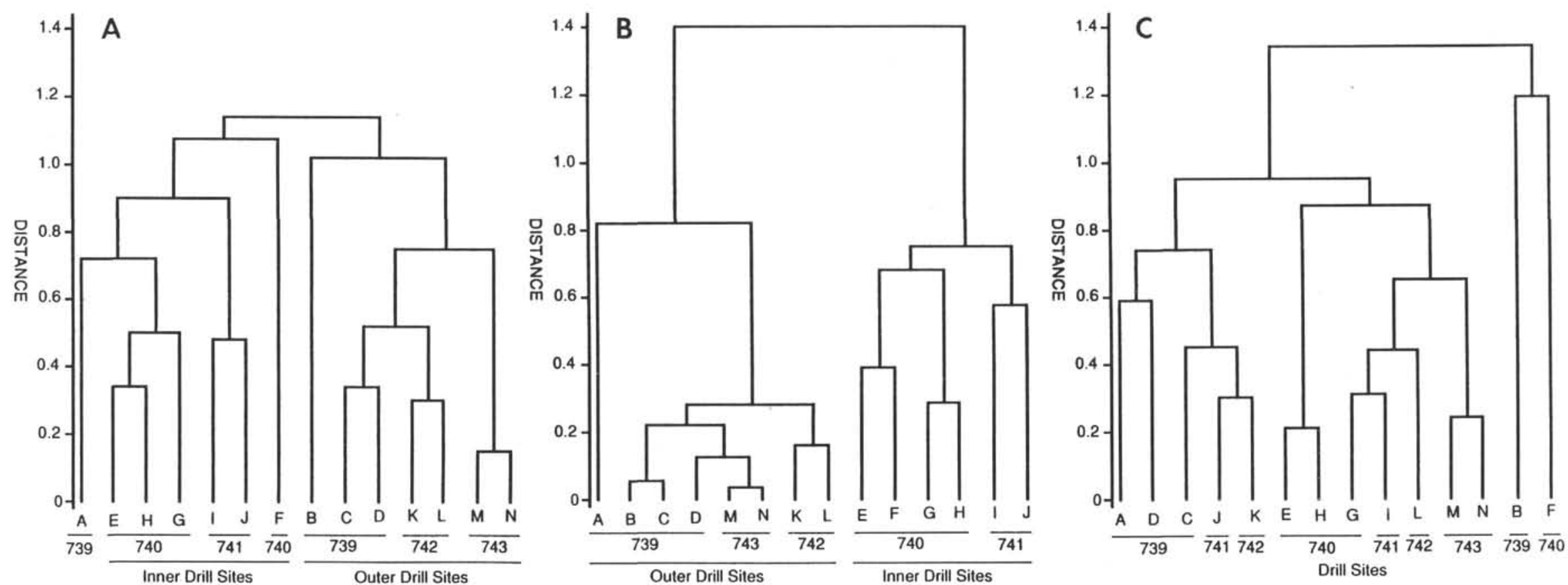

Figure 15. Clustering of stations, using integrated absolute abundances (cells $/ \mathrm{m}^{2}$ ) of eight dominant diatom species and total full diatoms (A), four larger-celled diatom species (B), and three small pennate diatoms (C) from the quantitative data. Symbols represent stations in the Prydz Bay drill sites: A, B, C, and D (Site 739, Stations 1, 2, 3, and 4); E, F, G, and H (Site 740, Stations 5, 6, 7, and 8); I and J (Site 741, Stations 9 and 10); K and L (Site 742, Stations 11 and 12); M and N (Site 743, Stations 13 and 14). Relative distance = average distance between clusters. 
samples (at seven depths) as variables revealed that the samples from the Prydz Bay drill sites not only separated based on depth (above thermocline vs. below thermocline), but they also separated based on station.

Cluster analysis using integrated absolute abundances (cells/ $\mathrm{m}^{2}$ ) of the dominant diatom species as variables showed the stations separated into the inner part of Prydz Bay (Sites 740 and 741) and the outer part of Prydz Bay (Sites 739, 742, and 743).

The clustering of stations was shown to vary depending on which variables were used for cluster analysis. When only largercelled diatom species were included in the analysis, stations separated clearly into the inner and outer parts. But when the cluster analysis was performed with only smaller-celled diatom species, the stations from inner and outer Prydz Bay intermingled, not separated clearly.

\section{ACKNOWLEDGMENTS}

We thank Jack G. Baldauf, Sayed Z. El-Sayed, and John D. McEachran for critically reviewing the manuscript and for providing helpful comments and discussion throughout the study. John Barron and an anonymous reviewer aided our revision. Il Noh, Steve Berkowitz, Dean Stockwell, and the Maersk Master captain, Peter Messmann, and his crew assisted with the sample collection, and their efforts are gratefully acknowledged. II Noh and Doug Biggs provided the chlorophyll $a$ data. Norzaini Mufti gave excellent technical support. Funding was provided by the National Science Foundation (Ocean Drilling Program account \#20200 and \# 55161).

\section{REFERENCES}

Allanson, B. R., Hart, R. C., and Lutjeharms, J.R.E., 1981. Observations on the nutrients, chlorophyll, and primary production of the Southern Ocean south of Africa. S. Afr. J. Antarct. Res., 10:3-14.

Boden, B. P., 1949. The diatoms collected by the U.S.S. Cacopan in the Antarctic in 1947. Sears Found. J. Mar. Res., 8:6-13.

Buck, K. R., and Garrison, D. L., 1983. Protists from the ice-edge region of the Weddell Sea. Deep-Sea Res., Part A, 30:1261-1277.

Crumpton, W. G., 1987. A simple and reliable method for making permanent mounts of phytoplankton for light and fluorescence microscopy. Limnol. Oceanogr., 32:1154-1159.

Deacon, G.E.R., 1982. Physical and biological zonation in the Southern Ocean. Deep-Sea Res., Part A, 29:1-16.

Denisov, A. S., and Myznhikova, M. N., 1978. Osobennosti gidrologicheskogo rezhima v zalive Priuds (fevral'1973 g.) Tr. Sov. Antarkt. Eksped., 68:100-105.

El-Sayed, S. Z., 1971. Observations on phytoplankton bloom in the Weddell Sea. In Llano, G. A., and Wallen, I. E. (Eds.), Biology of the Antarctic Sea (Vol. 4). Antarct. Res. Ser., 17:301-312.

El-Sayed, S. Z., Biggs, D. C., and Holm-Hansen, O., 1983. Phytoplankton standing crop, primary productivity, and near-surface nitrogenous nutrient fields in the Ross Sea, Antarctica. Deep-Sea Res., Part A, 30:871-886.

Evans, C. A., O' Reilly, J. E., and Thomas, J. P., 1987. A Handbook for the Measurement of Chlorophyll $a$ and Primary Production. BIOMASS Sci. Ser., 8.

Fryxell, G. A., 1977. Thalassiosira australis Peragallo and Thalassiosira lentiginosa (Janisch) G. Fryxell, comb. nov.: two Antarctic diatoms (Bacillariophyceae): Phycologia, 16:95-104.

1986. Microalgae at the ice edge in the northern Weddell Sea. Antarct. J. U.S., 21:166-168.

Fryxell, G. A., Doucette, G. J., and Hubbard, G. F., 1981. The genus Thalassiosira: the bipolar diatom Thalassiosira antarctica Comber. Bot. Mar., 24:321-335.

Fryxell, G. A., and Hasle, G. R., 1983. The Antarctic diatoms Thalassiosira dichotomica (Koslova) comb. nov. and T. ambigua Koslova. Polar Biol., 2:53-62.

Fryxell, G. A., Kang, S.-H., and Reap, M. E., 1987. AMERIEZ 1986: phytoplankton at the Weddell Sea ice edge. Antarct. J. U.S., 22:173-175.

Fryxell, G. A., and Kendrick, G. A., 1988. Austral spring microalgae across the Weddell Sea ice edge: spatial relationships found along a northward transect during AMERIEZ 83. Deep-Sea Res., Part A, 35:1-20.

Fryxell, G. A., Reap, M. E., and Kang, S.-H., 1988. Antarctic phytoplankton dominants, life stages, and indicators. Antarct. J. U.S., 23: 129-131.

Fryxell, G. A., Villareal, T. A., and Hoban, M. A., 1979. Thalassiosira scotia, sp. nov.: observation on a phytoplankton increase in early austral spring north of Scotia Ridge. J. Plankton Res., 1:355-370.

Garrison, D. L., and Buck, K. R., 1985. Sea-ice algal communities in the Weddell Sea: species composition in ice and plankton assemblages. In Gary, J. S., and Christiansen, M. E. (Eds.), Marine Biology of Polar Regions and Effects of Stress on Marine Organisms: New York (Wiley), 103-122.

Garrison, D. L., Buck, K. R., and Fryxell, G. A., 1987. Algal assemblages in Antarctic pack ice and in ice-edge plankton. J. Phycol., 23: 564-572.

Gordon, A. L., Molinelli, E., and Baker, T., 1978. Large-scale relative dynamic topography of the Southern Ocean. J. Geophys. Res., 83: 3023-3032.

Gould, R. W., Jr., 1988. Net phytoplankton in a Gulf Stream warmcore rings: species composition, relative abundance, and the chlorophyll maximum layer. Deep-Sea Res., Part A, 35:1595-1614.

Grigor'yev, Y. A., 1967. Circulation of the surface waters in Prydz Bay. Tr. Sov. Antarkt. Eksped., 7:74-76.

Hallegraeff, G. M., 1981. Seasonal study of phytoplankton pigments and species at a coastal station off Sydney: importance of diatoms and the nannoplankton. Mar. Biol., 61:107-118.

Hannah, F. J., and Boney, A. D., 1983. Nannophytoplankton in the Firth of Clyde, Scotland: seasonal abundance, carbon fixation and species composition. J. Exp. Mar. Bio. Ecol., 67:105-147.

Hart, T. J., 1942. Phytoplankton periodicity in Antarctic Surface Water. Discovery Rep., 21:263-348.

Hasle, G. R., 1956. Phytoplankton and hydrography of the Pacific part of the Antarctic Ocean. Nature, 177:616-617. 1964. Nitzschia and Fragilariopsis species of the groups Nitzschiella and Lanceolatae. Skr. Nor. Vidensk.-Akad. Kl. I: Mat.Naturvidensk Kl., 16:5-48.

1965a. Nitzschia and Fragilariopsis species studied in the light and electron microscopes. II. The group Pseudonitzschia. Skr. Nor. Vidensk.-Akad. Kl. I: Mat.-Naturvidensk Kl., 18:5-15.

1965b. Nitzschia and Fragilariopsis species in the light and electron microscopes. III. The genus Fragilariopsis. Skr. Nor. Vidensk.-Akad. KI. I: Mat.-Naturvidensk Kl., 21:5-49.

1968. Observation of the marine diatom Fragilariopsis kerguelensis (O'Meara) Hust. in the scanning electron microscope. Norw. J. Bot., 15:205-208.

1969. An analysis of the phytoplankton of the Pacific Southern Ocean: abundance, composition, and distribution during the Brategg Expedition, 1947-1948. Hvalradets. Skr, 52:1-168.

1972a. Fragilariopsis Hustedt as a section of the genus Nitzschia Hassall. Nova Hedwigia Beih., 54:15-66.

$1972 \mathrm{~b}$. The distribution of Nitzschia seriata Cleve and allied species. Nova Hedwigia Beih., 39:171-190.

1974. Validation of the names of some marine planktonic species of Nitzschia (Bacillariophyceae). Taxon, 23:425-428.

Hasle, G. R., Heimdal, B. R., and Fryxell, G. A., 1971. Morphologic variability in fasciculated diatoms as exemplified by Thalassiosira tumida (Jan.) Hasle, comb. nov. In Llano, G. A., and Wallen, I. E. (Eds.), Biology of the Antarctic Seas IV: Antarct. Res. Ser., 17:313333.

Hendey, N. J., 1937. The plankton diatoms of the Southern Ocean. Discovery Rep., 16:151-364.

Hewes, C. D., Reid, F.M.H., and Holm-Hansen, O., 1984. The quantitative analysis of nanoplankton: a study of methods. J. Plankton Res., 6:601-613.

Hustedt, F., 1958. Diatomeen aus der Antarktis und dem Sudatlantik. Dtsch. Antarkt. Exped. 1938-39, Wiss. Ergebn., 2:103-191.

Izvekov, M. V., 1959. Results of observations on currents in the region of the West Ice Shelf. Tr. Sov. Antarkt. Eksped., 2:91-93.

Jacobs, S. S., and Georgi, D. T., 1977. Observations on the southwest Indian Antarctic Ocean. In Angel, M. V. (Ed.), A Voyage of Discovery. Deep-Sea Research, Part A, (Suppl.), 24:43-84.

Jacques, G., Descolas-Gros, C., Grall, J.-R., and Sournia, A., 1979. Distribution du phytoplancton dans la partie Antarctique de 
l'Ocean Indien en fin d'ete. Int. Rev. Gesamten Hydrobiol., 64:609-628.

Johansen, J. R., and Fryxell, G. A., 1985. The genus Thalassiosira (Bacillariophyceae): studies on species occurring south of the Antarctic Convergence Zone. Phycologia, 24:155-179.

Kang, S.-H., and Fryxell, G. A., 1989. Comparative method of quantitative analysis of diatoms in water column assemblages in Prydz Bay, Antarctica, Ocean Drilling Program Leg 119. Eos, Trans. Am. Geophys. Union, 70:376. (Abstract)

Karsten, G., 1905. Das Phytoplankton des Antarktischen Meeres. In Chun, C. (Ed.), Wissenschaftliche Ergebnisse der deut Schen Tiefsee-Expedition 1898-1899: Jena (Gustav Fischer), 1-136.

Kopczynska, E. E., Weber, L. H., and El-Sayed, S. Z., 1986. Phytoplankton species composition and abundance in the Indian Sector of the Southern Ocean. Polar Biol., 6:161-169.

Kozlova, O. G., 1966. Diatoms of the Indian and Pacific Sectors of the Antarctic: (Translated from the Russian), Washington, D.C., (N.S.F.)

Leg 119 Shipboard Scientific Party, 1988. Early glaciation of Antarctica. Nature, 333:303-304.

Malone, T. C., 1980. Algal size. In Morris, I. (Ed.), The Physiological Ecology of Phytoplankton: London (Blackwell Scientific), 433-463.

Manguin, E., 1960. Les diatomees de la Terre Adelie campagne du Commandant Charcot, 1949-1950. Ann. Sci. Nat., Ser. A (Bot.), 12:223-363.

Marumo, R., 1957. The surface distribution of plankton diatoms in the western part of the Pacific Ocean and the Antarctic Ocean in 19541955. Oceanogr. Mag., 9:143-147.

Murphy, L. S., and Haugen, E. M., 1985. The distribution and abundance of phototrophic ultraplankton in the North Atlantic. Limnol. Oceanogr., 30:47-58.

Palmisano, A. C., SooHoo, J. B., SooHoo, S. L., Kottmeier, S. T., Craft, L. L., and Sullivan, C. W., 1986. Photoadaptation in Phaeocystis pouchetii advected beneath annual sea ice in McMurdo Sound, Antarctica. J. Plankton Res., 5:891-906.

Pomeroy, L. R., 1974. The ocean's food web: a changing paradigm. Bioscience, 24:499-504.

Priddle, J., and Fryxell, G. A., 1985. Handbook of the Common Plankton Diatoms of the Southern Ocean: Centrales Except the Genus Thalassiosira: London (British Antarctic Survey, Natural Environment Research Council).

Reid, F.M.H., 1983. Biomass estimate of components of the marine nanoplankton and picoplankton by the Utermohl settling technique. J. Plankion Res., 5:235-252.

Savatiugin, L. M., and Komova, V. V., 1971. Gidrologicheskaia kharakteristika zaliva Priuds v fevral 1969 g. Tr. Sov. Antarkt. Eksped., 57:99-104.

Seliger, H. H., McKinley, K. R., Biggley, W. H., Rivkin, R. B., and Aspden, K.R.H., 1981. Phytoplankton patchiness and frontal regions. Mar. Biol., 61:119-131.
Shaw, A. B., 1964. Time in Stratigraphy: New York (McGraw-Hill).

Smith, N. R., Zhaoqian, D. J., Kerry, K. R., and Wright, S., 1984. Water masses and circulation in the region of Prydz Bay, Antarctica. Deep-Sea Res. Part A, 31:1121-1147.

Smith, W. O., and Nelson, D. M., 1985. Phytoplankton bloom produced by a receding ice edge in the Ross Sea: spatial relationship with the density field. Science, 227:163-166.

Steyaert, J., 1973a. Difference in diatom abundance between the two summer periods of 1965 and 1967 in Antarctic inshore waters (Breid Bay). Inv. Pesq., 37:517-532.

, 1973b. Distribution of plankton diatoms along an AfricanAntarctic transect. Inv. Pesq., 37:295-328.

, 1974. Distribution of some selected diatom species during the Belgo-Dutch Antarctic expedition of 1964-65 and 1066-67. Inv. Pesq., 38:259-287.

Swithinbank, C.W.M., McClain, P., and Little, P., 1977. Drift tracks of Antarctic icebergs. Polar Rec., 18:495-501.

Tchernia, P., and Jeannin, P. F., 1980. Observations on the Antarctic East Wind drift using tabular icebergs tracked by satellite Nimbus $F$ (1975-1977). Deep-Sea Res., Part A, 27:467-474.

Tolstikov, E. E., 1966. Atlas Antarktiki (Vol. 1), Moscow (G.U.C.K.). (English translation, Soviet Geography: Reviews and Translations, Am. Geogr. Soc., 8 (1967).

Utermohl, H., 1958. Zur Vervollkomnung der quantitativen phytoplankton-Methodik. Mitt. Int. Ver. Theor. Angew. Limnol., 9.

Weber, L. H., and El-Sayed, S. Z., 1987. Contributions of the net, nano- and picoplankton to the phytoplankton standing crop and primary productivity in the Southern Ocean. J. Plankton Res., 9:973994.

Wilson, D. L., Smith, W. O., and Nelson, D. M., 1986. Phytoplankton bloom dynamics of the western Ross Sea ice edge: I. Primary productivity and species-specific production. Deep-Sea Res., Part A, 33:1375-1387.

Zernova, V. V., 1970. Phytoplankton of the Southern Ocean. In Holdgate, M. V. (Ed.), Antarctic Ecology: London (Academic Press) $136-142$.

Zverev, A. A., 1959. Anomalous sea water temperatures in Olaf Prydz Bay. Tr. Sov. Antarkt. Eksped., 1:269-271.

1963. Currents in the Indian sector of the Antarctic. Tr. Sov. Antarkt. Eksped., 17:144-155.

Date of initial receipt: 4 September 1989

Date of acceptance: 12 February 1990

Ms 119B-145 